\title{
Heterotrophic respiration in disturbed forests: A review with examples from North America
}

\author{
Mark E. Harmon, ${ }^{1}$ Ben Bond-Lamberty, ${ }^{2}$ Jianwu Tang, ${ }^{3}$ and Rodrigo Vargas ${ }^{4}$ \\ Received 28 July 2010; revised 3 February 2011; accepted 11 February 2011; published 14 May 2011.
}

[1] Heterotrophic respiration $\left(\mathrm{R}_{\mathrm{H}}\right)$ is a major process releasing carbon to the atmosphere and is essential to understanding carbon dynamics in terrestrial ecosystems. Here we review what is known about this flux as related to forest disturbance using examples from North America. The global $\mathrm{R}_{\mathrm{H}}$ flux from soils has been estimated at 53-57 $\mathrm{Pg} \mathrm{C} \mathrm{yr}^{-1}$, but this does not include contributions from other sources (i.e., dead wood, heart-rots).

Disturbance-related inputs likely account for $20-50 \%$ of all $\mathrm{R}_{\mathrm{H}}$ losses in forests, and disturbances lead to a reorganization of ecosystem carbon pools that influences how $R_{H}$ changes over succession. Multiple controls on $\mathrm{R}_{\mathrm{H}}$ related to climate, the material being decomposed, and the decomposers involved have been identified, but how each potentially interacts with disturbance remains an open question. An emerging paradigm of carbon dynamics suggests the possibility of multiple periods of carbon sinks and sources following disturbance; a large contributing factor is the possibility that postdisturbance $\mathrm{R}_{\mathrm{H}}$ does not always follow the monotonic decline assumed in the classic theory. Without a better understanding and modeling of $\mathrm{R}_{\mathrm{H}}$ and its controlling factors, it will be difficult to estimate, forecast, understand, and manage carbon balances of regions in which disturbance frequency and severity are changing. Meeting this challenge will require (1) improved field data on processes and stores, (2) an improved understanding of the physiological and environmental controls of $\mathrm{R}_{\mathrm{H}}$, and (3) a more formal analysis of how model structure influences the $R_{H}$ responses that can be predicted.

Citation: Harmon, M. E., B. Bond-Lamberty, J. Tang, and R. Vargas (2011), Heterotrophic respiration in disturbed forests: A review with examples from North America, J. Geophys. Res., 116, G00K04, doi:10.1029/2010JG001495.

\section{Introduction}

[2] Heterotrophic respiration $\left(\mathrm{R}_{\mathrm{H}}\right)$ is one of three major terrestrial processes releasing carbon to the atmosphere, the other two being autotrophic respiration $\left(\mathrm{R}_{\mathrm{A}}\right)$ and combustion. Over long times and large spatial extents these three fluxes, at least in upland ecosystems, roughly equal the amount of carbon being fixed by photosynthesis resulting in approximate carbon neutrality. Over short periods of time, or within small areas, changes in the strength of these fluxes can determine when and where an ecosystem is a source or sink of carbon relative to the atmosphere [Fisher et al., 2008]. Thus, the understanding of the biophysical factors that regulate the strength of these fluxes is a current research topic of carbon dynamics in terrestrial ecosystems.

\footnotetext{
${ }^{1}$ Department of Forest Ecosystems and Society, Oregon State University, Corvallis, Oregon, USA.

${ }^{2}$ Joint Global Change Research Institute, Pacific Northwest National Laboratory/University of Maryland, College Park, Maryland, USA.

${ }^{3}$ The Ecosystems Center, Marine Biological Laboratory, Woods Hole, Massachusetts, USA.

${ }^{4}$ Departamento de Biología de la Conservación, Centro de Investigación Científica y de Educación Superior de Ensenada, Ensenada, Mexico.

Copyright 2011 by the American Geophysical Union. 0148-0227/11/2010JG001495
}

[3] A major process determining the relative strength of these fluxes is disturbance. While what is considered a disturbance in a forest ecosystem is scale dependent [Pickett and White, 1985], common ones such as fire, windstorms, insect outbreak, and timber harvest affect entire landscapes creating spatial patterns and biologic legacy structures (e.g., dead wood) that last decades to centuries [Foster et al., 1998]. Functionally, disturbances can have significant impacts on the carbon balances of large regions by influencing carbon flux components such as $\mathrm{R}_{\mathrm{H}}$ [Zeng et al., 2009; Kurz et al., 2008].

[4] At the scale of a forest stand (i.e., a small area) classic ecosystem theory [Odum, 1969] predicts that following a stand replacing disturbance, $\mathrm{R}_{\mathrm{H}}$ losses initially exceed gains via net primary production (i.e., NPP = photosynthesis $\mathrm{R}_{\mathrm{A}}$ ). This is because the disturbance converts live vegetation into dead material that decomposes, changes ambient soil conditions, and temporally decreases the ability of the ecosystem to gain carbon via plant photosynthesis. As a result net ecosystem production (i.e., NEP $=$ NPP $-R_{H}$ ) is negative which means the ecosystem is a source of carbon to the atmosphere (Figure 1). In time, the dead material created by disturbance decomposes away and photosynthesis recovers, resulting in an ecosystem carbon sink. If allowed to progress undisturbed for a long period, greater and 

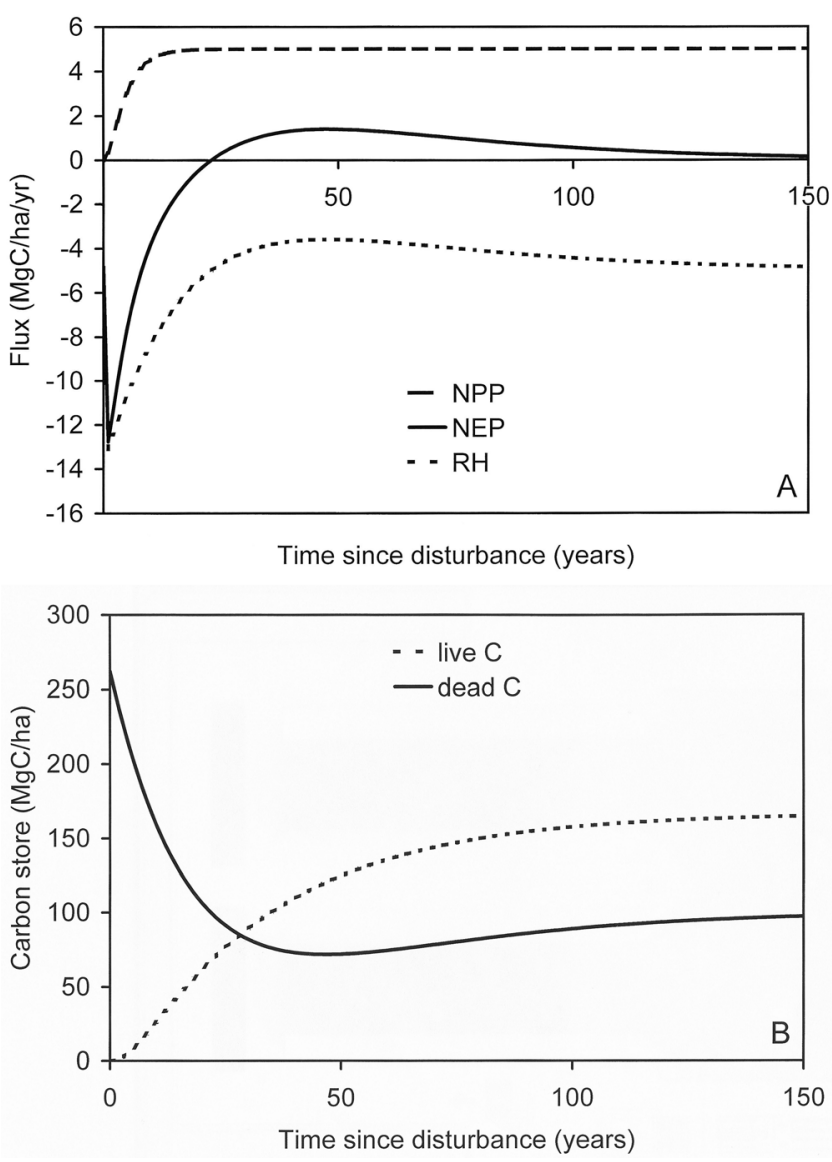

Figure 1. The classic pattern of (a) net primary production (NPP), heterotrophic respiration $\left(\mathrm{R}_{\mathrm{H}}\right)$ and net ecosystem production (NEP) and (b) associated carbon stores following a catastrophic (i.e., stand replacing) disturbance.

greater amounts of production replace dying parts (i.e., leaves, roots, and stems) and the accumulation of all those dead parts leads to an increase in $R_{H}$ which eventually equals the flux associated with production. Depending on the biome this sequence may repeat over decades to centuries.

[5] A number of studies have confirmed the general outlines of the classic theory [Janisch and Harmon, 2002; Luyssaert et al., 2008; Wirth et al., 2002]; although there is some question whether NEP ever reaches zero during the latter stages of succession [Luyssaert et al., 2008], there is little doubt that it declines after reaching a peak. However, an emerging paradigm suggests that in some ecosystems there may be multiple periods of carbon sinks and sources following disturbance [Amiro et al., 2006; Bond-Lamberty et al., 2004b; Goulden et al., 2010; Litvak et al., 2003]. The cause of this complex response is currently under investigation, but a large contributing factor is the possibility that postdisturbance $R_{H}$ does not always follow the monotonic decline assumed in the classic theory. This suggests that greater attention needs to be paid to the factors controlling $\mathrm{R}_{\mathrm{H}}$ and its timing following disturbance, particularly as respiration in gen- eral is less well understood than other major carbon fluxes [Trumbore, 2006].

[6] As part of a North American Carbon Program (NACP) synthesis activity our goal in this paper is to review how disturbance influences $\mathrm{R}_{\mathrm{H}}$, the factors that control this important flux, and the implications of this process on the temporal and spatial pattern of ecosystem carbon balance. We also consider how $R_{H}$ is currently measured and modeled, making suggestions how these need to be modified to predict the level of complexity now being observed for NEP following disturbance. We present examples generally taken from North America, but many of the principles presented should apply to any forest system undergoing disturbance. Our review contains several general themes: (1) Sources of $\mathrm{R}_{\mathrm{H}}$ are diverse and understanding of $\mathrm{R}_{\mathrm{H}}$ following disturbance currently is hampered by incomplete knowledge of many contributing sources and controls of this flux, (2) variations in disturbance profiles (i.e., the carbon structures impacted), frequency, and severity have a large influence on the magnitude and temporal pattern of $\mathrm{R}_{\mathrm{H}}$, with major implications for regional carbon balances, and (3) predicting transient responses (e.g., the impact of changing disturbance regimes) in the temporally and spatially explicit manner required to match inversion model predictions will not be possible until the interaction of disturbance legacies and climate at the macroscale and microscale is better understood.

\section{General Aspects of $\mathbf{R}_{\mathbf{H}}$}

[7] In terrestrial ecosystems, $R_{H}$ is associated with a wide diversity of structures created by mortality, disturbance, grazing, extensive decomposition, and stabilization mechanisms [Sollins et al., 1996]. These include soil organic matter [Chapin et al., 2006], root exudates [Kuzyakov and Larionova, 2005], woody detritus [Harmon et al., 1986; Pedlar et al., 2002], dead branches [Christenssen, 1977], heart-rots [Harmon et al., 2004], and organic matter accumulation in forest canopies [Enloe et al., 2006] (Table 1). While aggregation of $R_{H}$ sources is often necessary, some forms of simplification exclude pools and significantly violate conservation of mass, having the potential to create artificial carbon sinks with respect to the atmosphere. For example, neglecting $\mathrm{R}_{\mathrm{H}}$ associated with dead wood (until recently a common practice) can overestimate carbon sinks associated with forest regions subject to disturbance [Zeng et al., 2009]. Factors that should be considered in segregating $\mathrm{R}_{\mathrm{H}}$ fluxes are the trophic source of the carbon (live versus dead), the type of material being respired (leafy versus woody), the size, and the position of the material (buried versus downed versus suspended) as well as the degree of stabilization of the material (litter versus soil C). Regardless of the scheme used, the functional relationship between sources needs to be considered. For example, soil $\mathrm{C}$ is derived from dead leaves, roots, and to a lesser extent stems; it should be functionally related to these contributing pools in either any analysis or model.

[8] By reorganizing ecosystem carbon pools, disturbances have major impacts on the size and source of the $R_{H}$ flux (Figure 2). How $R_{H}$ changes immediately after disturbance depends on the type and severity of disturbance, degree to 
Table 1. Forms of Carbon Contributing to Heterotrophic Respiration $\left(\mathrm{R}_{\mathrm{H}}\right)$ in a Forest

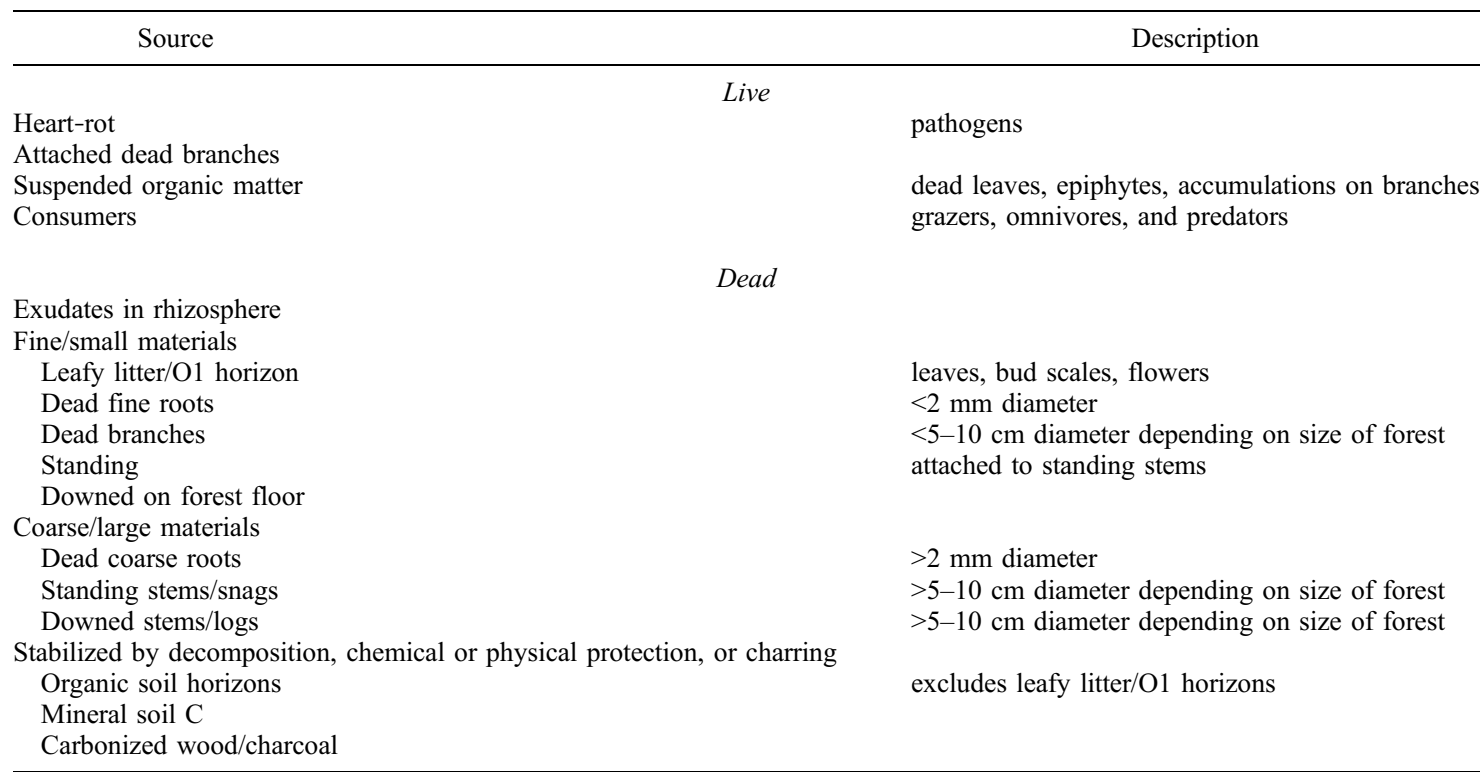

Boreal stores

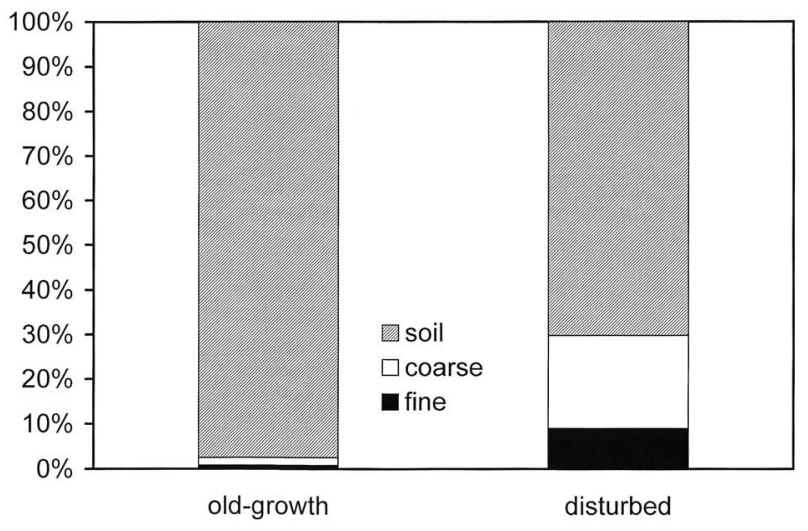

Boreal flux

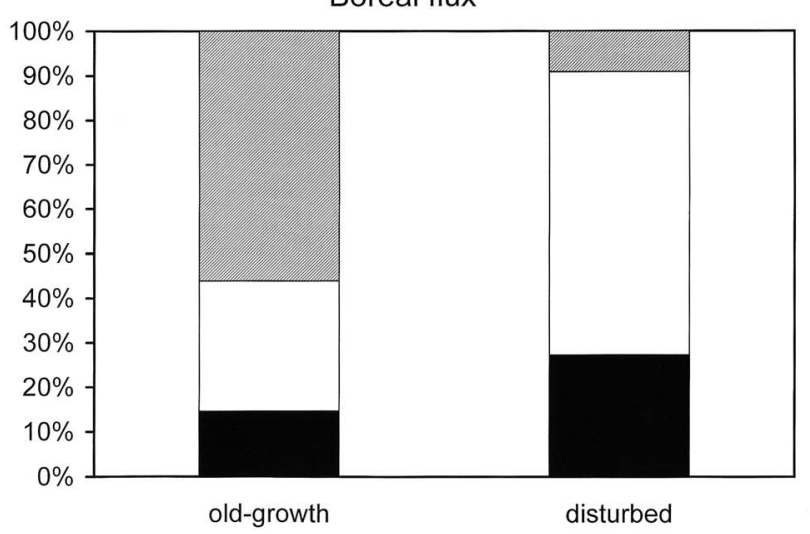

PNW stores

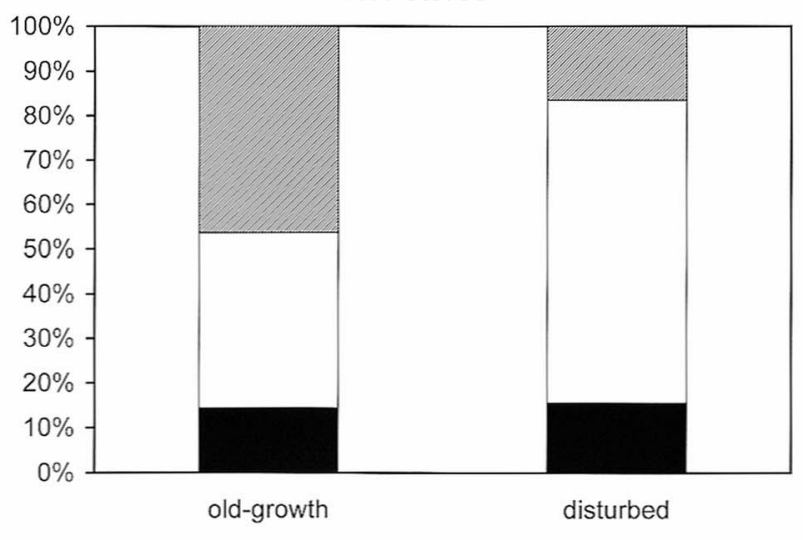

PNW flux

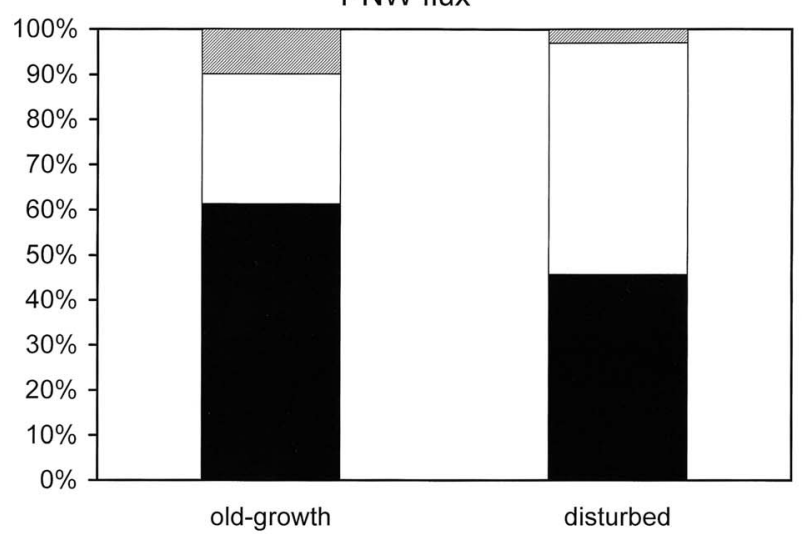

Figure 2. Relative contribution of $\mathrm{R}_{\mathrm{H}}$ sources and related stores in old-growth and recently disturbed forests for two different regions. Soil includes mineral and organic horizons in boreal and mineral only in the Pacific Northwest (PNW). Coarse and fine are separated by size and degree of woodiness. PNW values based on Harmon et al. [2004]. Boreal values based on Wang et al. [2002]. 


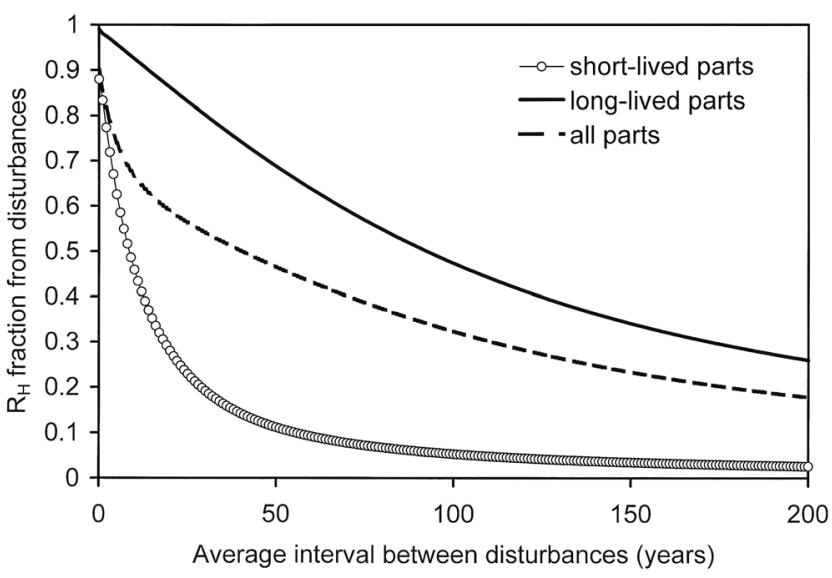

Figure 3. The hypothetical fraction of heterotrophic respiration $\left(\mathrm{R}_{\mathrm{H}}\right)$ associated with disturbance inputs for shortlived ( $<5$ years), long-lived ( $>50$ years), and a mix of plant parts typically found in forests (5\% short-lived and $95 \%$ long-lived parts).

which the disturbance removes legacy carbon (i.e., consumption in fire or removal by harvest reduces the flux), and changes the relative size of the pools contributing to $R_{H}$. Note that our use of severity follows that of Keeley [2009], describing the "immediate" loss and change of ecosystem carbon brought about by disturbances. In section 5, we consider the long-term response of $\mathrm{R}_{\mathrm{H}}$ to disturbance type and severity. In cases where there is a very large accumulation of mineral soil carbon and/or low accumulations of live woody tissues, disturbance may not lead to major changes in the source of $\mathrm{R}_{\mathrm{H}}$ fluxes. However, where large accumulations of live woody tissues prevail, such as forests of the Pacific Northwest, disturbance can quickly create a system where dead wood becomes a significant carbon store and source of $\mathrm{R}_{\mathrm{H}}$.

[9] Disturbance leads to a feedback between the live and dead parts of an ecosystem. Longer periods between disturbance lead to a larger accumulation of live carbon, but this in turn leads to a larger input of dead material when a disturbance occurs and the greater the reductions in live carbon by disturbance, the greater the increase in dead carbon and consequently $\mathrm{R}_{\mathrm{H}}$. Theoretically this feedback loop causes the net ecosystem carbon balance (NECB) to approach zero in a landscape when a disturbance regime of a given frequency and severity (i.e., amount of carbon removed) is maintained [Smithwick et al., 2007].

[10] Despite the short and infrequent exposure of ecosystems to disturbances, a substantial proportion of carbon decomposed by forest heterotrophs can be associated with disturbances (Figure 3) [Harmon et al., 1986]. This proportion is dependent on the longevity of plant parts: the longer-lived the part, the more $\mathrm{R}_{\mathrm{H}}$ associated with disturbance. Moreover, as the average interval between disturbances increases, the lower the portion of $\mathrm{R}_{\mathrm{H}}$ associated with disturbance. As the severity of disturbance decreases, the inputs from disturbance presumably declines, as would the fraction of $\mathrm{R}_{\mathrm{H}}$ associated with disturbances. Given the mixtures of short- versus long-lived parts typically found in forests, decomposing inputs from stand replacing dis- turbances are likely associated with 20 to $50 \%$ of total $\mathrm{R}_{\mathrm{H}}$ depending upon the average disturbance interval (Figure 3 ).

\section{Estimates of $\mathbf{R}_{\mathbf{H}}$}

[11] Compared to other key ecosystem carbon fluxes, $\mathrm{R}_{\mathrm{H}}$ is quite large, although its magnitude is often highly uncertain [Trumbore, 2006], because (1) soil C flux is a difficult-to-separate combination of belowground $\mathrm{R}_{\mathrm{H}}$, root respiration, and associated mycorrhizal respiration [Vogt et al., 1982] and (2) it is difficult to estimate dead wood and heart-rot losses. The global $\mathrm{R}_{\mathrm{H}}$ flux from soils has been estimated at 53-57 $\mathrm{Pg} \mathrm{C} \mathrm{yr}^{-1}$ [Bond-Lamberty and Thomson, 2010b; Potter and Klooster, 1998] with yearto-year variability of $\sim 1 \mathrm{Pg} \mathrm{C}$. At the ecosystem scale, $\mathrm{R}_{\mathrm{H}}$ is typically $30-80 \%$ of total annual soil surface $\mathrm{CO}_{2}$ flux [Hanson et al., 2000; Mahecha et al., 2010], varying seasonally [Epron et al., 1999; Mo et al., 2005; Tang and Baldocchi, 2005], because of the high variability in belowground autotrophic respiration [Davidson et al., 2006; Sampson et al., 2007; Vargas et al., 2010a, 2010b, 2010c]. Variation in the proportion of $\mathrm{R}_{\mathrm{H}}$ to total ecosystem respiration is largely explained by forest type and climate; although after disturbance it can account for $100 \%$ of respiration losses [e.g., Wang et al., 2002] indicating time since disturbance also needs to be considered. Ecosystem-level $\mathrm{R}_{\mathrm{H}}$ fluxes of $11-1359 \mathrm{~g} \mathrm{C} \mathrm{m}^{-2} \mathrm{yr}^{-1}$ are reported in a recently assembled soil $\mathrm{CO}_{2}$ flux database [Bond-Lamberty and Thomson, 2010a] with the highest fluxes reported in a tropical forest after a hurricane disturbance [Vargas and Allen, 2008]. These fluxes are comparable or exceed the global mean of $1081 \pm 128 \mathrm{~g} \mathrm{C} \mathrm{m}^{-2}$ ecosystem respiration measured using the eddy covariance technique compiled by a global data set based on FLUXNET sites [Baldocchi, 2008].

[12] Few studies have directly measured $\mathrm{R}_{\mathrm{H}}$ from decomposing woody debris (using, e.g., an infrared gas analyzer) and these are mostly in stands that have not been recently disturbed. Table 2 summarizes published estimates that extrapolate annual ecosystem-level values [cf. Marra and Edmonds, 1996] for this flux. In general, downed CWD respiration in undisturbed forests accounts for 10 $20 \%$ of total $\mathrm{R}_{\mathrm{H}}$ [Bond-Lamberty et al., 2004b]. Largerscale estimates of the impact of disturbance on CWD $\mathrm{R}_{\mathrm{H}}$ are few (although see Zeng et al. [2009]). As an example of its potential, in Figure 4 we present an estimate for the integrated woody debris respiration flux from North American boreal forests; these forests have low biomass, but severe disturbance, with frequent wildfires in the central and western part of the continent [Pan et al., 2010]. The range of this estimated annual flux (40-60 $\mathrm{Tg} \mathrm{yr}^{-1}$ ) is an appreciable fraction of the Canadian and North American carbon sink estimates [U.S. Climate Change Science Program, 2007; Houghton, 2003], and large enough to significantly affect atmospheric inverse modeling studies that focus on subcontinental scales [Deng et al., 2007]. As another example, Zeng et al. [2009] found that disturbance from tropical cyclones in the eastern United States released an average of $25 \mathrm{Tg} \mathrm{C} \mathrm{yr}{ }^{-1}$ between 1851 and 2000; a value equivalent to $9-18 \%$ of the $C$ sink associated with tree growth for the entire United States. Therefore excluding the $R_{H}$ associated with dead wood, a common past practice, is 
Table 2. Direct Measurements of Woody Debris Respiration Rates, Extrapolated to Annual Stand Level

\begin{tabular}{|c|c|c|c|c|}
\hline Ecosystem Type and Disturbance & Stand Age(s) & CWD Pool (Mg C ha $\left.{ }^{-1}\right)$ & Respiration $\left(\mathrm{Mg} \mathrm{C} \mathrm{ha}{ }^{-1} \mathrm{yr}^{-1}\right)$ & Source $^{a}$ \\
\hline Boreal Pinus banksiana, logged & $0-79$ & $7-12$ & $0.1-0.5$ & 1 \\
\hline Boreal Picea mariana, fire & $2-152$ & $1-178$ & $0.1-1.9$ & 2 \\
\hline Temperate hardwood, fire/logging & 85 & 2.2 & 0.2 & 3 \\
\hline Temperate hardwood, pathogen & 30 & 9.3 & 0.5 & 4 \\
\hline Temperate hardwood, old growth & $>350$ & N/A & 0.43 & 5 \\
\hline Temperate conifer, old growth & $>350$ & $\mathrm{~N} / \mathrm{A}$ & 0.29 & 5 \\
\hline Tropical & $>1000$ & 14.9 & 1.9 & 6 \\
\hline
\end{tabular}

a Sources: 1, Howard et al. [2004]; 2, Bond-Lamberty et al. [2002]; 3, Gough et al. [2007]; 4, Jomura et al. [2007]; 5, Tang et al. [2008]; 6, Chambers et al. [2001].

likely to significantly compromise forest carbon balance calculations especially when disturbances are present and could influence national carbon policy decisions [Kurz et al., 2008].

\section{Controls on $\mathbf{R}_{\mathbf{H}}$}

[13] There are multiple controls on $R_{H}$ related to climate, the material being processed, and the organisms involved in the processing (Figure 5), all potentially interacting with disturbance. Thus, to understand how $\mathrm{R}_{\mathrm{H}}$ varies after disturbance it is important to understand how these controls interact with this process.

[14] Temperature has been the most frequently examined control of $\mathrm{R}_{\mathrm{H}}$ [Curiel Yuste et al., 2007]. However, it is still unclear whether the $\mathrm{R}_{\mathrm{H}}$ temperature response varies spatially at large scales [Mahecha et al., 2010; Zhou et al., 2009], but there are certainly different controls at the hourly, daily, and seasonal timescales [Vargas et al., 2010c]. As temperature increases the rate of $R_{H}$ generally increases exponentially in the short term, although eventually plateaus or decreases [Bradford et al., 2008; Kirschbaum, 2006; Lloyd and Taylor, 1994; Luo et al., 2001]. Its longer-term temperature sensitivity is debated: some hypothesize that temperature sensitivity is lower for well decomposed substrates, yet others the opposite [Conant et al., 2008; Fang et al., 2005; Fierer et al., 2005; Fissore et al., 2009; Gershenson et al., 2009; Giardina and Ryan, 2000; Hakkenberg et al., 2008; Mahecha et al., 2010]. The potential consequences on the global carbon cycle are tremendous, but currently unresolved [Davidson and Janssens, 2006]. Finally, given that soil respiration is a mix of autotrophic and heterotrophic sources, their relative temperature sensitivity will influence the overall sensitivity of soil C flux to temperature [Boone et al., 1998; Rustad et al., 2000]. This is currently poorly understood; partially due to methodological inconsistencies that complicate comparisons between studies [Graf et al., 2008].

[15] The other key climatically related control of $R_{H}$ involves the abundance of water in decomposing substrates and soil [Howard and Howard, 1993]. While precipitation is often correlated to $\mathrm{R}_{\mathrm{H}}$ rates, moisture of the substrate is the actual mechanistic control [Griffin, 1977]. At low moisture contents (expressed on a mass basis), water is held too strongly by the substrate itself to be available for decomposers (the so-called matric limitation), but above the fiber saturation point $(\sim 30 \%)$ water becomes available to decomposers [Boddy, 1983; Griffin, 1977; Marra and Edmonds, 1996; Orchard and Cook, 1983]. Moisture content becomes too high when voids in the substrate become filled with water.
This leads to a reduction of diffusion rates of oxygen, which then becomes limiting for aerobic respiration [Bunnell et al., 1977; Griffin, 1977]. This oxygen diffusion limitation is stronger as the particle size of the decomposing substrate increases in part because oxygen has further to travel and in part because larger pieces dry at a slower rate [Viney, 1991]. Thus large pieces of wood become "water logged" before small ones and fine leafy litter needs to be literally submerged before these effects are observed. While long-term averages (e.g., monthly) of moisture content are typically considered, the frequency of drying-rewetting cycles can impact longterm $\mathrm{R}_{\mathrm{H}}$ [Fierer and Schimel, 2002].

[16] While controls of soil moisture are well studied [Hillel, 1998], those for other substrates such as large dead wood are poorly understood; however, there are several important general controls of these aboveground materials

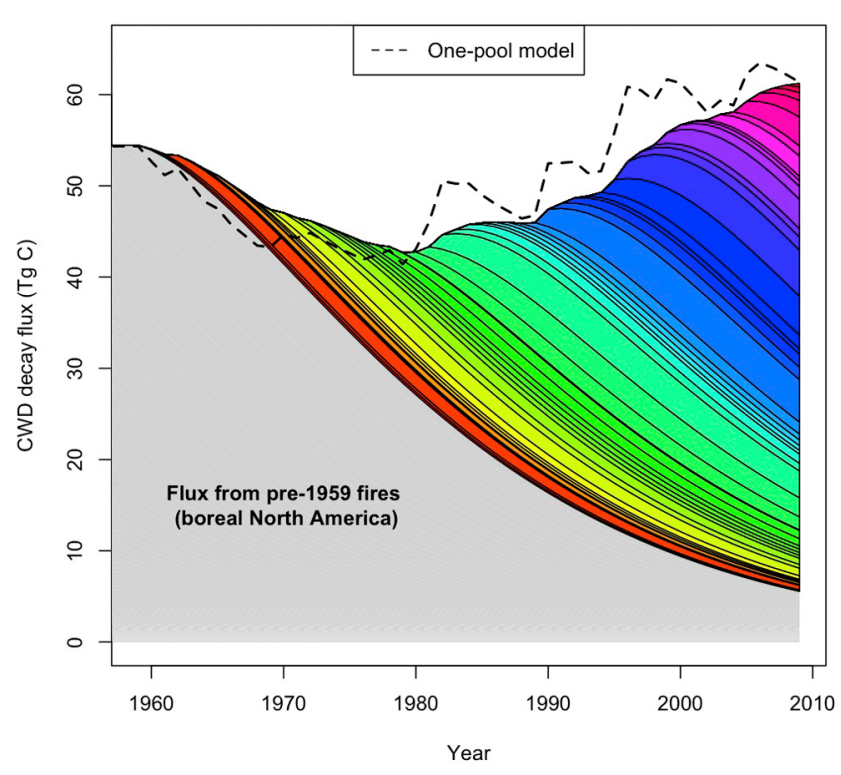

Figure 4. Estimated annual carbon flux from coarse woody debris (CWD) across boreal North America, based on known fire history (1959-2009) and simple assumptions about prefire stand biomass and postfire CWD decay rates. Different colors show the flux from different CWD cohorts, by year of fire, using a simple model also shown; in general the temporal trends of the single- and dual-pool models are out of phase due to lags in decomposition associated with snag fall. 
A
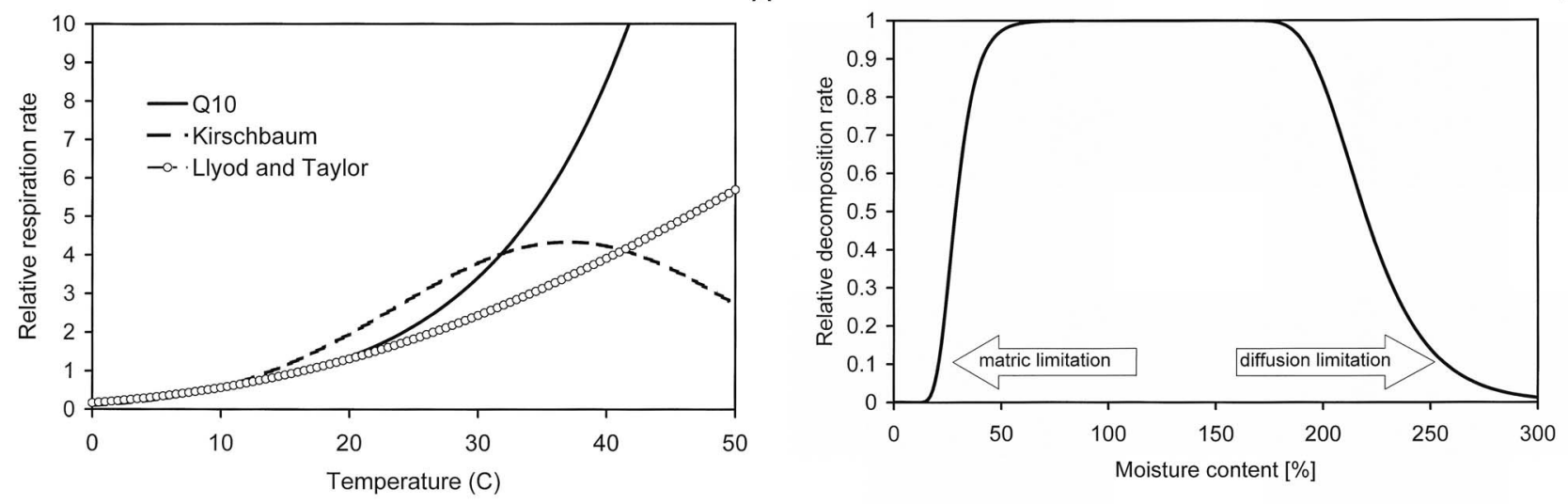

C
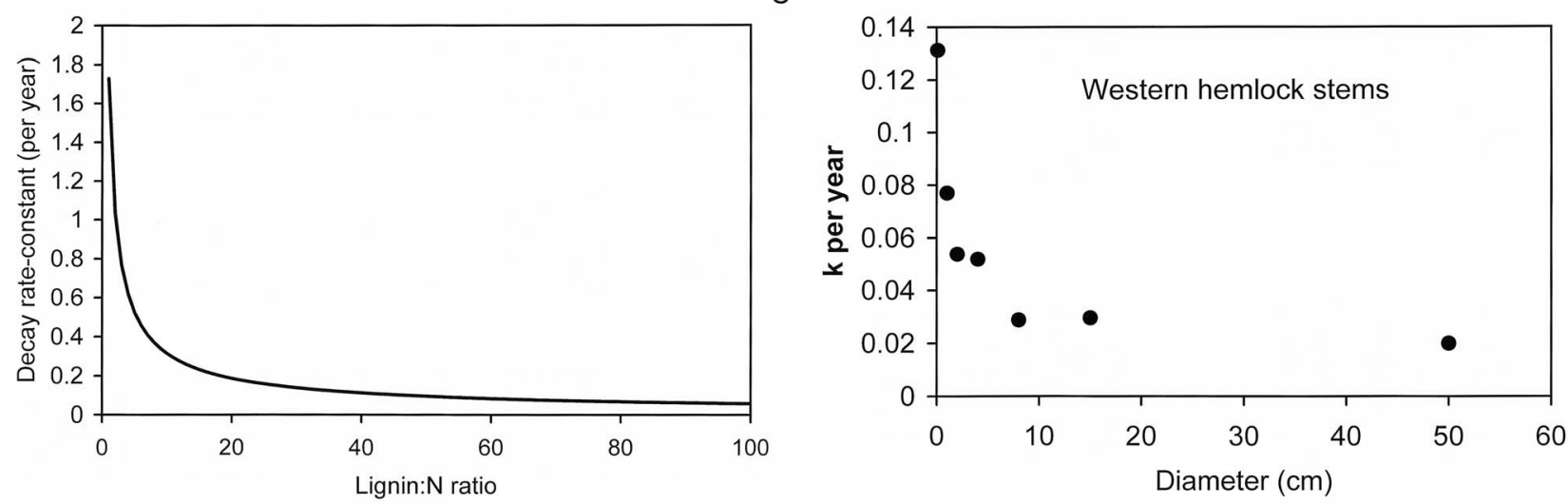

Figure 5. Examples of factors controls of heterotophic respiration $\left(\mathrm{R}_{\mathrm{H}}\right)$ : (a) temperature [Kirschbaum, 2006; Lloyd and Taylor, 1994], (b) mass-based moisture content [Harmon, 2009], (c) lignin:N ratio [Harmon et al., 1996], and (d) size.

that have been studied in the field of fire science [Simard and Main, 1982; Rothermel et al., 1986; Viney, 1991]. The smaller the diameter of the substrate, the faster it will dry [Brackebusch, 1975; Fosberg, 1971; Viney, 1991]. Material exposed to more solar radiation dries faster, which means that drying rates are higher in forests with lower canopy cover [Byram and Jemison, 1943]. Covered and buried substrates dry more slowly than those exposed on the surface [Brackebusch, 1975]; suspended substrates dry faster than those on the forest floor, which in turn dry faster than substrates within the mineral soil. Vertically oriented substrates (e.g., standing dead stems) likely intercept less precipitation than those oriented horizontally (e.g., logs) [Simard and Main, 1982]. The interactions of these factors lead to situations where the moisture content of the same substrate (e.g., dead stems) can differ substantially within the space of meters [Boulanger and Sirois, 2006]. While many of the controls on moisture content are physical (i.e., water deposition and evaporation), decomposer organisms themselves have an influence by adding water created via respiration [Griffin, 1977] or regulating water flows by creating hydrophobic substances [Unestan, 1991].

[17] The range of decomposition rates observed for substrates at a site provide insights into the physical and chemical influences substrates exert on $\mathrm{R}_{\mathrm{H}}$ (Figure 6). Common indices of chemical substrate quality include lig- nin and nitrogen $(\mathrm{N})$ concentrations, as well as $\mathrm{C}: \mathrm{N}$ and lignin:N ratios [Coûteaux et al., 1995; Melillo et al., 1982; Silver and Miya, 2001]. These are useful but mechanistically unclear, because (1) these chemical entities are difficult to separate in experiments (e.g., litter with high $\mathrm{N}$ often has low lignin concentrations and vice versa), resulting in

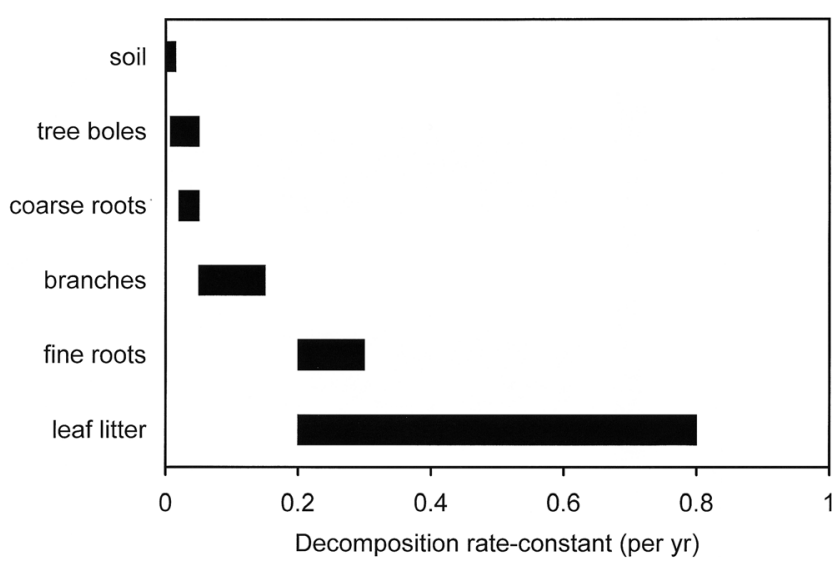

Figure 6. Range of decomposition rates for pools contributing to heterotrophic respiration $\left(\mathrm{R}_{\mathrm{H}}\right)$ for temperate conifer forest in the Pacific Northwest. 
observational studies with a high degree of confounding; (2) it is difficult to chemically analyze some constituents except in a very general manner (i.e., water soluble extractives, nonpolar extractives, acid resistant fraction, and acid hydrolysable fraction) [Ryan et al., 1990]; (3) minor secondary compounds such as tannins and resins can strongly influence decomposition particularly in wood and bark [Harmon et al., 1986; Mackensen et al., 2003; Scheffer and Cowling, 1966]; and (4) chemical substrate quality evolves during decomposition [Coûteaux et al., 1995]. Perhaps the most significant example of the second point is lignin, a compound that is very difficult to precisely quantify using traditional methods [Ryan et al., 1990]. The resulting mismatch between the actual chemistry and operational approximations of substrates can undermine the conceptual basis and mechanistic understanding of the decomposition process [Preston et al., 1997].

[18] While chemically based indices have been effectively used for fine litter (i.e., leaves and fine roots), physical factors are often insightful for other forms of carbon such as wood and those associated with mineral soil. Woody litter is often separated based on size because of its effect on (1) time to colonize material, (2) surface area volume ratio, and (3) change in substrate quality [Harmon et al., 1986]. The larger the size of material, the longer it will take for decomposers to colonize completely. As diameter increases, the lower the surface to volume ratio becomes and the slower the exchange of gases such as carbon dioxide, oxygen, and water vapor. Therefore in dry environments, increasing size can, in theory, lead to increased moisture retention, and hence maintain $\mathrm{R}_{\mathrm{H}}$ for longer periods than for smaller sizes. However, in very humid environments, greater moisture retention with increasing size can theoretically contribute to waterlogging reducing the period $\mathrm{R}_{\mathrm{H}}$ can occur. At least for woody materials, the proportion of tissues changes with size and since these tissues have different substrate qualities, the overall substrate quality can change with size [Harmon et al., 1986]. This effect will hypothetically be observed most strongly in species with decay-resistant heartwoods: as diameter increases more and more of the piece is composed of decay-resistant heartwood. A physical feature important in mineral soil is soil microaggregation, which protects soil organic matter from microbial decomposition due to limited microbial and enzyme access and oxygen availability [Davidson and Janssens, 2006; Six et al., 2002]. Forested soil has more organic matter aggregates than agricultural soil [Six et al., 2002], and forest harvest may result in the decrease in microaggregates and increase the loss of soil organic carbon [Diochon and Kellman, 2009].

[19] While rarely explicitly included in carbon models, decomposer organisms do influence the decomposition [ $\mathrm{Adl}$, 2003]. Perhaps the best appreciated effects of organisms are caused by the presence of macroinvertebrates such as termites [Wood, 1976]. However, whether the fungi degrading wood is a white-rot versus brown-rot can potentially also have a profound effect on $\mathrm{R}_{\mathrm{H}}$ [Bradford et al., 2010; Gilbertson, 1980; Kirk and Highley, 1973]. White-rot fungi can degrade lignin, hemicellulose, and cellulose, often preferring lignin over the polysaccharide-based polymers. This runs counter to several current detritus decomposition models which tacitly assume the presence of brown-rots, which degrade hemicelluloses and cellulose but not lignin. The kind of fungal decomposer present has major impacts on the accumulation of well-decomposed material. For example, woody detritus decomposed by brown-rots are likely to result in a substantial residue of relatively stable organic matter, while those with white-rots will not [Gilbertson, 1980]. Moreover, there is some evidence that white-rots decompose wood substantially faster than brownrots. For example, two species with identical carbon chemistry [Harmon, 1992] have decomposition rate constants that differ by a factor of two; the one degraded by white-rots being faster.

[20] In addition to the above controls on biotic decomposers and substrates, solar radiation can directly break down dead wood and litter without microbial involvement via photodegradation. This process could cause a significant proportion of carbon loss from litter in arid ecosystems [Brandt et al., 2009]. The effect of photodegradation in decomposition is reported to be influenced by moisture [Smith et al., 2010] and lignin content of plant litter [Austin and Ballare, 2010].

[21] The controls described above are not independent of disturbances, as this process can change the nature of the substrate being decomposed and microclimate in which it occurs. Disturbances may alter the carbon legacy to different degrees: the high temperatures encountered during fire may lead to different substrate quality than that created by either a windstorm [Fritze et al., 1993; Pietikäinen and Fritze, 1993] or insect attack. By temporarily reducing photosynthesis, disturbances can reduce the amount of high quality carbon supporting $R_{H}$ in the rhizophere. As the interval between disturbances decreases, the size of decomposing wood should decrease, which all other things being equal should increase decomposition rates [Harmon, 2009]. If the species dominating different succession stages vary in substrate quality, then changing disturbance intervals will likely lead to differences in decomposition rates [Harmon, 2009]. In general it can be theorized that substrate quality decreases the longer the interval becomes because the proportion of litter formed from leaves (versus wood) decreases; however, in forests this proportion is likely to remain stable after the initial stages of succession. Disturbance can also affect $\mathrm{R}_{\mathrm{H}}$ indirectly through changing microclimate [Wang et al., 2002]. For example, forest harvest significantly increased soil temperature due to decreases in canopy shading, surface litter covering, and latent heat fluxes thus affecting $R_{H}$ [Tang et al., 2009]. By reducing canopy shading, disturbances could increase drying rates of aboveground substrates [Byram and Jemison, 1943].

\section{Temporal Patterns of $\mathbf{R}_{\mathbf{H}}$ Following Disturbance}

[22] The classic theory [Odum, 1969] describes a single pulse of elevated $\mathrm{R}_{\mathrm{H}}$ associated with disturbance that follows a montonic pattern (i.e., a constant proportion of carbon being lost over time). However, several studies have found $\mathrm{R}_{\mathrm{H}}$ dynamics that might not match the Odum framework [e.g., Goulden et al., 2010], thus the factors controlling the temporal pattern of $\mathrm{R}_{\mathrm{H}}$ following disturbance are important to understand. 
Full legacy

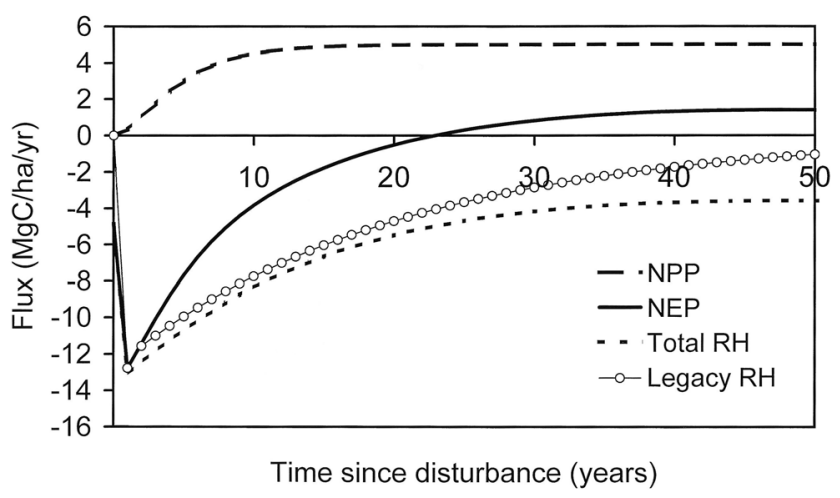

Partial legacy- $50 \%$

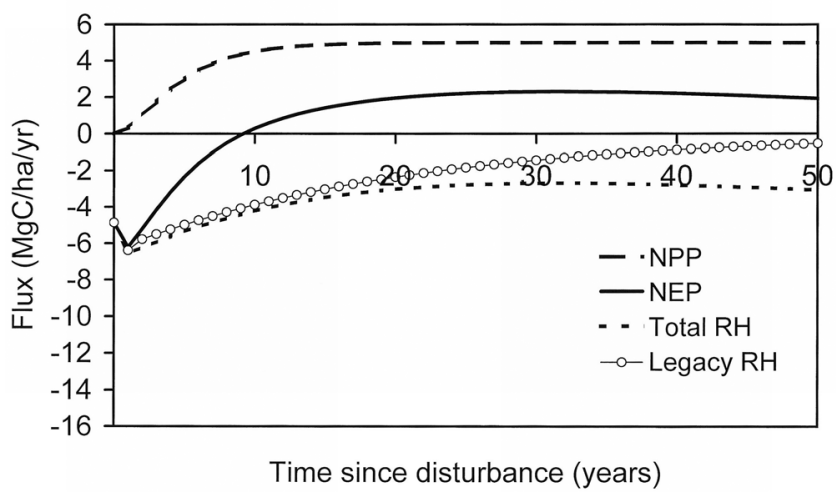

Figure 7. Hypothesized effects of the size of disturbancerelated dead legacy and heterotrophic respiration $\left(\mathrm{R}_{\mathrm{H}}\right)$ and net ecosystem production (NEP). $\mathrm{R}_{\mathrm{H}}$ is shown as that associated with the disturbance-related legacies and total $\mathrm{R}_{\mathrm{H}}$.

[23] The amount of legacy detritus left by disturbance clearly determines the cumulative amount of $\mathrm{R}_{\mathrm{H}}$, but it also controls the time at which NEP and NECB switch from negative (source to the atmosphere) to positive (sink from the atmosphere). The amount of legacy detritus depends on the disturbance type and severity as well as size of the organic soil pool. In general, as disturbance severity increases the amount live carbon converted to dead carbon increases, although disturbance types differ in their ability to cause mortality. In addition, fire and harvests remove both live and dead carbon legacies and when extremely severe can remove soil legacies [Bormann et al., 2008]. For example, natural disturbance in biomes with minimal organic soil pools, fire leaves intermediate to high amounts, while insect outbreaks and windthrow leave the highest amounts of legacy carbon [Roberts, 2004]. In biomes with large organic soil pools, smoldering ground fires can remove very large amounts of carbon and leave minimal legacies. The legacies associated with timber harvest are highly variable and depend on the utilization standards as well site preparation practices used [Harmon et al., 1996; Roberts, 2007].

[24] The times when NEP and NECB switch from source to sink are controlled by the interactions among the size of the carbon legacy, the rate it decomposes, and the rate at which NPP returns to predisturbance levels following succession [Amiro, 2001; Harmon, 2009]. For a given temporal pattern of NPP "recovery," the larger the legacy, the longer it takes for NEP and NECB to switch from a source to a sink (Figure 7). As an indication of the variation in switch times that is possible with different legacy amounts, Janisch and Harmon [2002] found in the Pacific Northwest that source-sink switch could occur in as few as 14 years or as many as 50 years. Boreal forests tend to exhibit much shorter transition times with the source-switch occurring in 5-15 years [Amiro, 2001; Litvak et al., 2003].

[25] As the decomposition rate increases for a given amount of disturbance-related legacy, the greater the magnitude of the $\mathrm{R}_{\mathrm{H}}$ pulse and the shorter it becomes. However, this hypothesis is based on a single aggregated source of $\mathrm{R}_{\mathrm{H}}$ following disturbance. Although some degree of aggregation of $\mathrm{R}_{\mathrm{H}}$ sources is necessary, the wide range in substrate qualities created by disturbances can lead to nonlinear temporal patterns difficult to capture using a single average; hypothetical examples these nonlinear behaviors are the losses of carbon following hurricane on the Yucatan Peninsula and blow down in the Pacific Northwest (Figure 8). Aggregating multiple forms of detritus misses an initial spike of $R_{H}$ release in both ecosystems. This means that the mixture and quality of materials created by disturbance needs to be carefully considered if the location and timing of $R_{H}$ is to be realistically estimated.

[26] If lags occur in either disturbance-related mortality or the decomposition of material created by disturbance, then the $\mathrm{R}_{\mathrm{H}}$ pulse can theoretically be offset from the disturbance (Figure 9). While disturbances are often envisioned as instantaneous events, their impact on mortality may stretch out many years [Boone et al., 1998; Lambert et al., 1980]. This causes a lag between the points in time the disturbance starts versus the peak of the $R_{H}$ pulse. It may also be the case that the disturbance occurs instantaneously, but mortality is delayed. For example, following blow-down of trees it may take years for trees to die [Cooper-Ellis et al., 1999]. Delayed $\mathrm{R}_{\mathrm{H}}$ pulses could be caused by slow colonization by decomposers (e.g., extremely large material) or temporarily unfavorable environmental conditions (e.g., a lack of moisture). In the case of disturbances creating standing dead trees in dry environments, such as bark beetle outbreaks, both kinds of delays may be involved. Here colonization may be limited by excessive drying as long as dead trees remain standing. For standing dead trees fall to the ground, roots and the lower stem may need to decompose, therefore it may take decades for decomposers to fully establish [Manies et al., 2005].

[27] In addition to single pulses of $R_{H}$ following disturbance, multiple pulses are theoretically possible when the multiple forms of detritus created by disturbance have lags of different duration. Many disturbances, fire and insects in particular, leave large stores of standing dead trees [Moroni, 2006]. Two $\mathrm{R}_{\mathrm{H}}$ pulses may follow these disturbances, but this depends on the relative environmental favorableness of standing versus downed versus soil legacies [Harmon, 2009]. In environments where these microsites are equally favorable for decomposition one is likely to see a single pulse that follows a nonlinear temporal pattern (see above). In environments in which the standing material is in a less favorable environment 


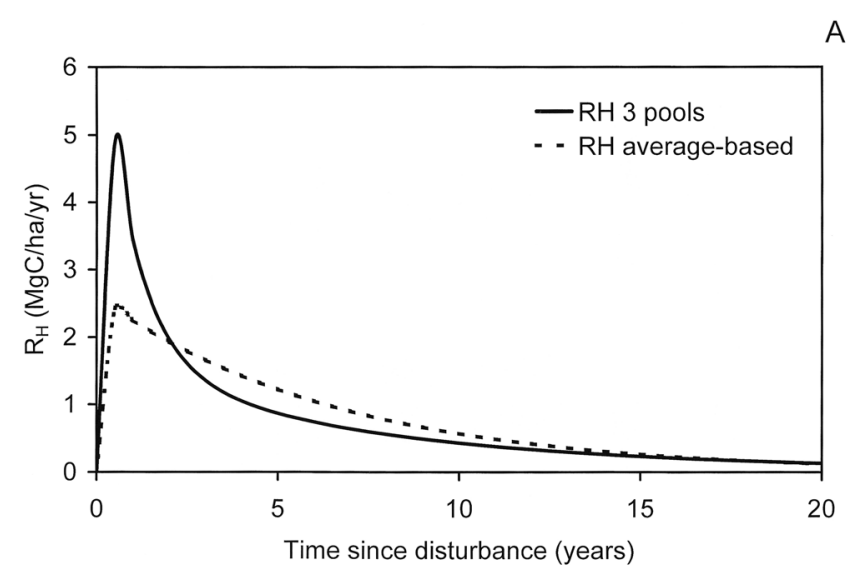

B

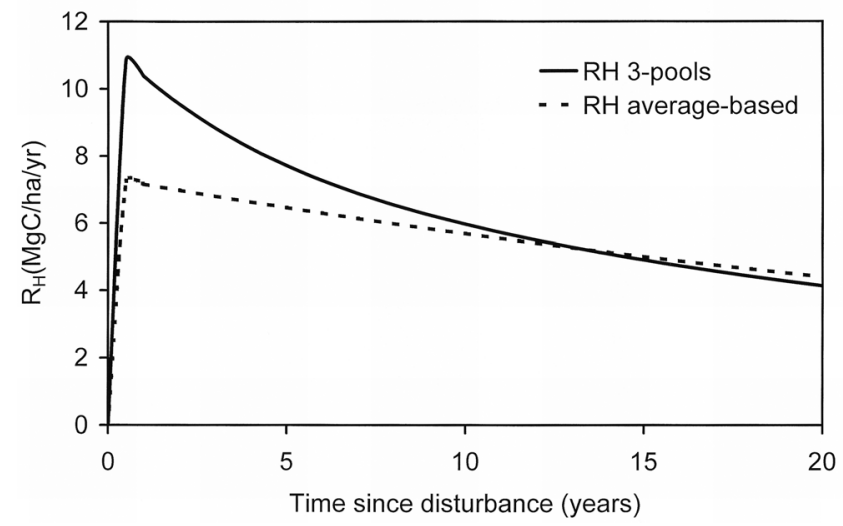

Figure 8. Hypothesized effect of heterogeneous substrate quality of disturbance-related dead carbon legacies on the temporal pattern of $\mathrm{R}_{\mathrm{H}}$. Based on response to (a) hurricane on the Yucatan Peninsula and (b) windthrow in the Pacific Northwest.

than either that of downed material or within the soil, then a double pulse is possible (Figure 10). This is because the root systems of standing dead trees can have substantial decomposition, while the standing stems and branches have minimal decomposition. Eventually, extensive coarse root decomposition leads to the stems and branches falling to the forest floor where faster decomposition occurs, leading to a secondary pulse of $\mathrm{R}_{\mathrm{H}}$. A variety of eddy covariance studies in central and western Canada have indicated respiration pulses at 20-30 years postdisturbance [Amiro et al., 2006], exactly the time at which boreal standing dead trees would be predicted to fall [Storaunet and Rolstad, 2004] and start decomposing at much higher rates. Studies in a Manitoba chronosequence also found such an upsurge in $\mathrm{R}_{\mathrm{H}}$ and change in net carbon balance, with woody debris respiration, rather than soil $\mathrm{R}_{\mathrm{H}}$, responsible [Bond-Lamberty et al., 2004b; Wang et al., 2002].

[28] Complex temporal patterns in $\mathrm{R}_{\mathrm{H}}$ can also be caused by differences in detritus inputs from the postdisturbance forest (Figure 11). The classic model does not consider heterogeneity of NPP allocation or the lifespan of detritus; essentially all parts are aggregated as either live or dead C. This leads to a monotonic increase in $R_{H}$ associated with this de novo dead carbon. However, NPP in forests is

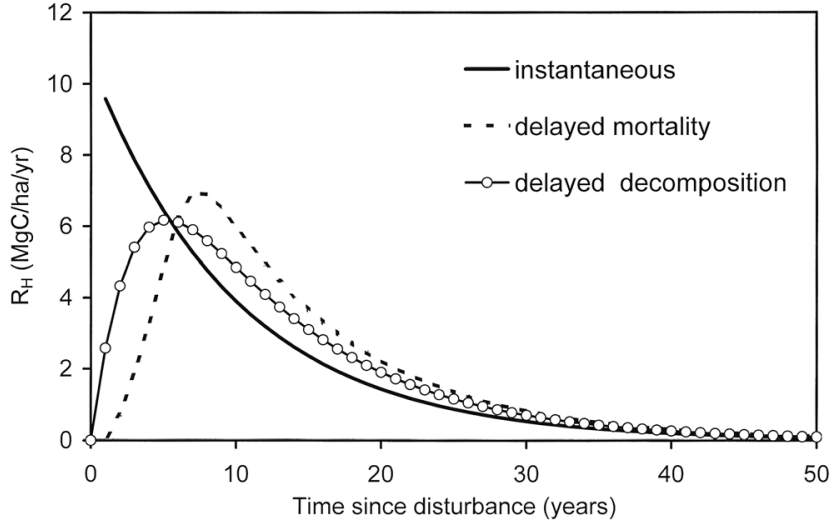

Figure 9. Hypothetical lags in heterotrophic respiration $\left(\mathrm{R}_{\mathrm{H}}\right)$ following disturbance caused by delayed mortality [e.g., Lambert et al., 1980] or delayed decomposition. For the instantaneous case the mortality pulse occurred in the first year, and the decomposition rate constant (i.e., proportion lost per year) did not change over time. For the delayed mortality case, disturbance mortality was assumed to peak at year 5 and be completed by year 10. For the delayed decomposition case the decomposition rate constant increased until year 10. All cases assumed that disturbance created $100 \mathrm{Mg} \mathrm{C} / \mathrm{ha}$.

allocated to parts that have lifespans that differ by orders of magnitude (e.g., wood versus leaves). Typically allocation to short-lived parts and plants is initially higher early in succession, which means there are lags in allocation to longer-lived ones and thus more complex $\mathrm{R}_{\mathrm{H}}$ temporal trends. Hypothetically, the longer the lag in allocation to longer-lived parts, the more likely secondary peaks of $R_{H}$ will occur.

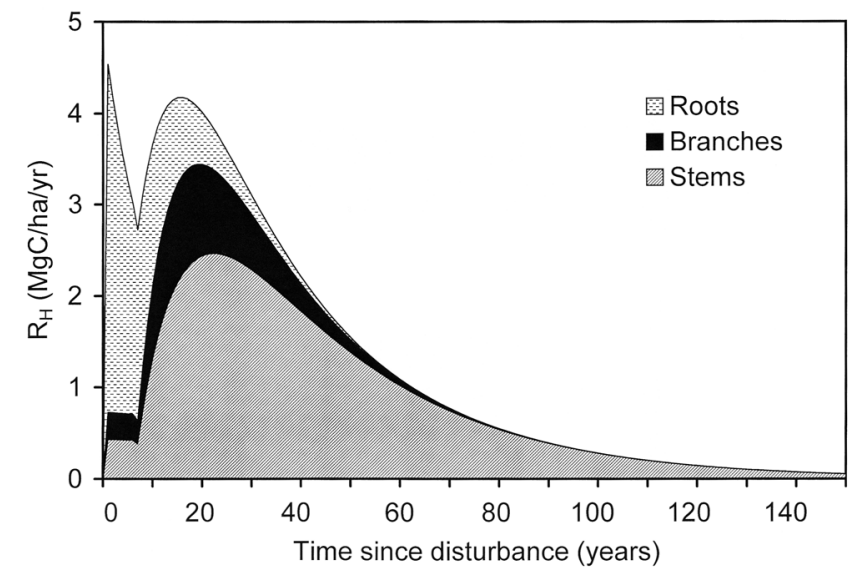

Figure 10. Hypothetical multiple pulses in $\mathrm{R}_{\mathrm{H}}$ caused by lags in decomposition and heterogeneous disturbancerelated dead carbon legacies. This assumes that disturbance creates standing dead wood that decomposes at $10 \%$ the value of downed wood. Roots are assumed to decompose relatively quickly leading standing dead wood to begin falling to the ground after 10 years. Roots and downed branches are assumed to decompose 3 times faster than downed stems. 


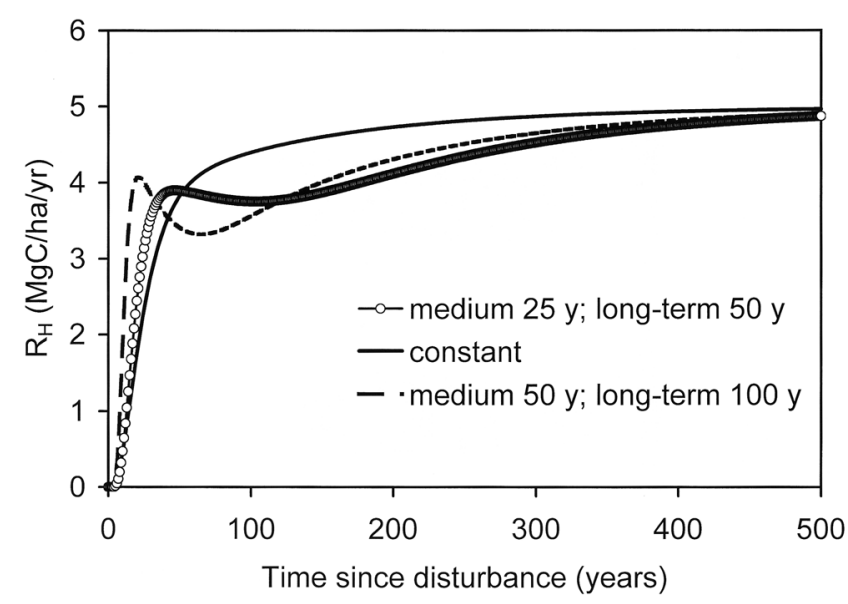

Figure 11. Hypothetical temporal patterns of $R_{H}$ associated with dead inputs associated with the postdisturbance forest (i.e., de novo C). The constant model assumes there are three pools of live and dead with differing lifespans (i.e., leaves, branches and coarse roots, and stems) but that their allocation does not change as forests age. In the other two cases the allocation into short-, medium-, and long-lived pools is 50,25 , and $25 \%$, respectively. These two cases differ from each other; one has allocation to medium- and longlived pools reach a maximum at 25 and 50 years, respectively; the other has allocation to medium- and long-lived pools reach a maximum at 50 and 100 years, respectively.

[29] The temporal patterns of $\mathrm{R}_{\mathrm{H}}$ described above, coupled with temporal trends in NPP and the microclimates of decomposing materials are hypothesized to strongly influence the temporal pattern of NEP and NECB. We examined how the different live, dead, and soil carbon legacies left by different disturbance types influence temporal trends in $\mathrm{R}_{\mathrm{H}}$ in an environment dry enough to cause differences in standing versus downed dead respiration rates (Figure 12). In the case of windthrow, some live plants remain capable of production and no dead or soil $\mathrm{C}$ legacies are removed. This leads to the largest peak of $\mathrm{R}_{\mathrm{H}}$, and a generally decreasing amount of $R_{H}$ as forests age. Although a beetle-kill has similar effects, it creates standing dead material with a slow respiration rate, leading to two peaks in $\mathrm{R}_{\mathrm{H}}$ and NEP. Had this beetle-kill occurred in a wet environment, the temporal pattern would be very similar to that of a windthrow. Severe wildfire not only kills all the vegetation, reducing initial NPP, but also reduces dead and soil C legacies. This greatly reduces the initial peak in $\mathrm{R}_{\mathrm{H}}$, increases the relative magnitude of the secondary peak, and could also cause NEP to have two positive periods. Timber harvest without a site preparation fire leaves a small live C legacy, but does not greatly increase the dead wood legacy because much of this $\mathrm{C}$ is removed. This might lead to a rapid pulse in $R_{H}$ associated with respiration of dead leaves, followed by a gradual increase as longer-lived $\mathrm{C}$ is produced. This kind of disturbance could cause NEP to remain near balance during the early phases of succession. Finally, a harvest followed by a site preparation fire leaves little live legacy, removes much of the dead legacy, and removes some soil C, reducing the initial $R_{H}$ pulse to the point that temporal patterns associated with de novo $\mathrm{C}$ dominate. This kind of disturbance could also create two peaks in NEP, the first associated with the rapid increase in production and mortality of short-lived plant parts, and the second associated with that of longer-lived plant parts. While these examples are hypothetical, they illustrate that monotonic changes in $\mathrm{R}_{\mathrm{H}}$ might be less likely than generally supposed.

\section{Measuring $\mathbf{R}_{\mathbf{H}}$}

[30] To confirm the temporal patterns suggested above $R_{H}$ needs to be measured. Unfortunately measurements of this flux have high uncertainties. Given the multiple sources of $\mathrm{R}_{\mathrm{H}}$, it is difficult to measure this flux completely. This is no different than NPP in that the bulk of NPP estimates focus on several easily measured components while ignoring others [Clark et al., 2001]. Unfortunately, the components of NPP that are easy to routinely measure in forests (i.e., aboveground litter production and stem growth) do not completely match those routinely measured for $R_{H}$ (soil respiration, much of which is driven by root production) potentially leading to highly uncertain ecosystem carbon balances.

[31] In the cases of heart-rot and soil-related $R_{H}$, autotrophic and heterotrophic fluxes are commingled, making the estimation of ecosystem-level $\mathrm{R}_{\mathrm{H}}$ uncertain. Estimating the soil $\mathrm{R}_{\mathrm{H}}$ flux has received the most attention to date with multiple reviews considering this difficult problem [Hanson et al., 2000; Högberg et al., 2001; Kuzyakov and Larionova, 2005; Scott-Denton et al., 2006; Trumbore, 2006; Vargas et al., 2010b]. Typically the soil surface $\mathrm{C}$ flux is partitioned into the respiration from free-living soil microorganisms that oxidize soil organic matter and respiration from plant roots, associated mycorrhizal fungi, and the local rhizosphere (i.e., the organic exudates emanating from the roots) [Kuzyakov and Larionova, 2005; Scott-Denton et al., 2006]. These source fluxes can be separated by techniques such as trenched plots [Jassal and Black, 2006], tree girdling [Hanson et al., 2000] and radiocarbon [Hahn et al., 2006], but measuring and modeling soil respired carbon associated with heterotrophs remains a significant challenge.

[32] Regardless of source, respiration fluxes can be directly measured using chambers, profiles, or eddy covariance methods. Chamber-based measurement of $\mathrm{CO}_{2}$ fluxes have evolved from fixed and portable chambers into automated systems for continuous and semicontinuous measurements [e.g., Goulden and Crill, 1997]. The weakness of the chamber measurement systems stems either from the disturbance of air pressure or altering $\mathrm{CO}_{2}$ concentration profile in the soil when the chamber is enclosed [Davidson et al., 2002; Livingston and Hutchinson, 1995]. As an alternative to chambers, belowground $\mathrm{CO}_{2}$ profiles have been recently developed to estimate surface $\mathrm{CO}_{2}$ fluxes by automatically measuring $\mathrm{CO}_{2}$ concentration in different layers in soils [Jassal et al., 2005; Tang et al., 2005, 2003; Vargas and Allen, 2008; Vargas et al., 2010a]. The challenge of the profile method is measuring and modeling of $\mathrm{CO}_{2}$ diffusivity in soils, a critical component to calculate flux that varies instantaneously with moisture content and other microclimate factors. The understory eddy covariance method has also been used in measuring $\mathrm{CO}_{2}$ fluxes from 

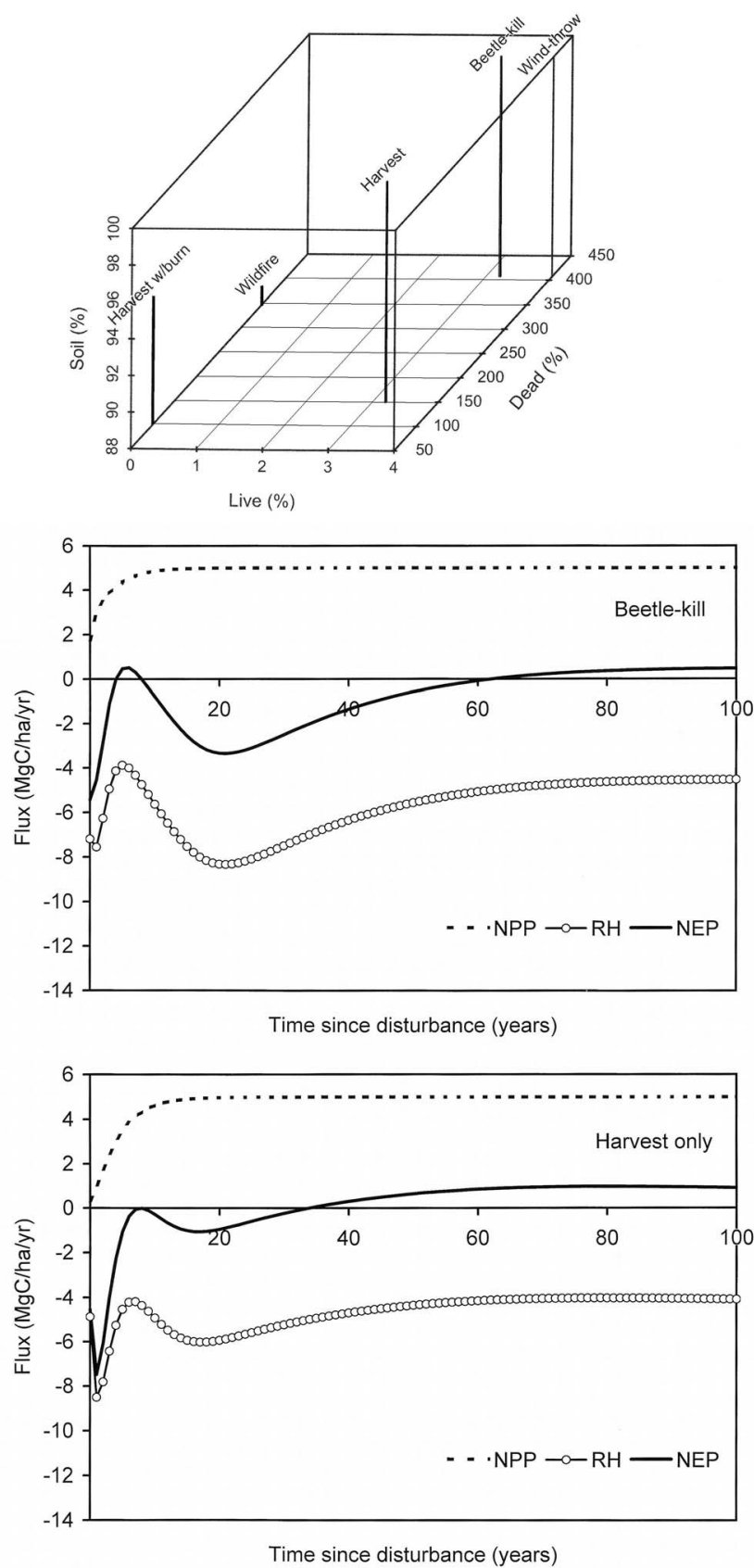
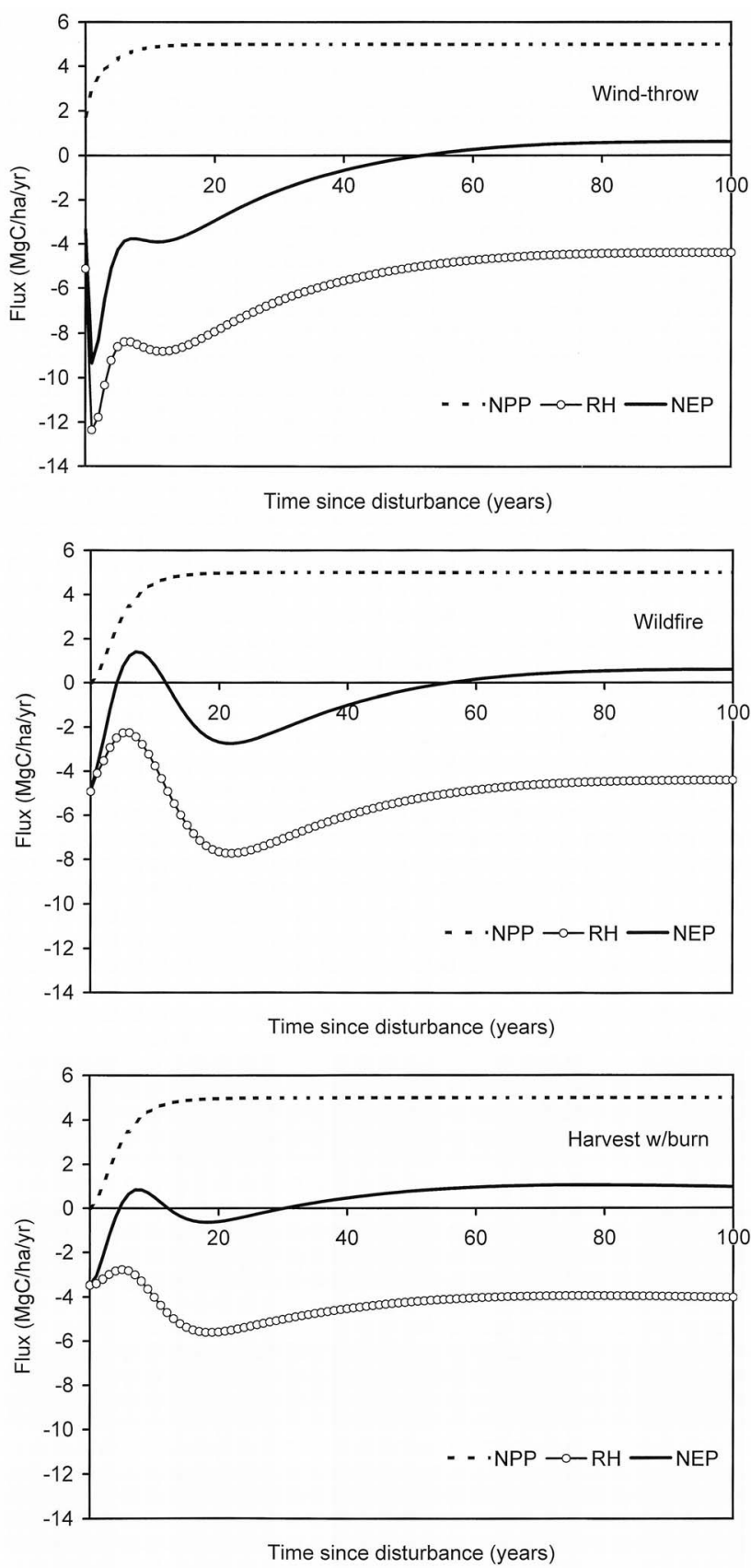

Figure 12. Hypothetical examples of temporal patterns of NPP, $\mathrm{R}_{\mathrm{H}}$, and NEP associated with different disturbance types in a "dry" environment in which standing dead C decomposes more slowly than downed dead C. In the model used to produce these examples, the live and dead pools were divided into three lifespans (i.e., short-, medium-, and long-lived) and the soil into a slow and very slow pool. For all examples, NPP is assumed to reach a maximum in 10 years; allocation to parts with a medium lifespan (e.g., branches and coarse roots), and long lifespans (e.g., stems) is assumed to peak at 25 and 50 years, respectively. Allocation to short-, medium-, and long-lived parts was 50,25, and 25\%, respectively. Disturbance shown include windthrow, beetle-kill, wildfire, harvest without fire, and harvest with fire; for more details, see text. (top left) The character of the legacies left by hypothetical "severe" disturbances.

soils [Baldocchi and Meyers, 1991; Law et al., 1999]. However, understory eddy covariance faces challenges in correcting for weak turbulence, drainage flow (i.e., advection), and uncertainty in footprint areas, as well as separating autotrophic versus heterotrophic sources. At the ecosystem level it is theoretically possible to estimate total ecosystem respiration $\left(R_{E}\right)$ using eddy covariance methods, but not $R_{H}$. Moreover, it is likely is $R_{E}$ is not as well determined as production-related fluxes such as NPP and gross primary production [Lavigne et al., 1997]. 
[33] An indirect method to estimate $R_{H}$ flux is based on multiplying the decomposition rate constant by the pool size of the component in question. For example, in tropical forests affected by hurricanes, $\mathrm{R}_{\mathrm{H}}$ was estimated based on measurements of biomass and decomposition rate constants [Harmon et al., 1995; Ostertag et al., 2003; Vargas and Allen, 2008]. This produces long-term estimates that match the kinds of calculations made in most models, but has several weaknesses. The first is that decomposition rates, such as those for CWD summarized by Rock et al. [2008] reflect not only respiration losses, but those associated with leaching and fragmentation. As the latter two losses do not necessarily result in immediate release of $\mathrm{CO}_{2}$ to the atmosphere, their use may lead to overestimates of $\mathrm{R}_{\mathrm{H}}$. Second, knowledge of decomposition rate constants for various pools does not proportionally match the contribution that these pools make to $\mathrm{R}_{\mathrm{H}}$. Thus one finds leaf decomposition studies dominate the literature compared to those on fine root, coarse roots, branch, and stem (including heart-rot); yet in forests these latter forms of detritus make large contributions to disturbance-related $\mathrm{R}_{\mathrm{H}}$. Third, determining the decomposition rate constant, and inversely the turnover time, of mineral soil carbon pools has proven difficult, although isotopic analysis has provided key insights [Trumbore, 2006]. Fourth, far more is known about turnover times than pool sizes, leading to another knowledge mismatch [Houghton et al., 2009]. While mineral soil stores estimates could be improved, many thousands of samples have been taken globally. In contrast, the size of organic horizon pools and woody detritus pool sizes have rarely been measured; thus estimates of $R_{H}$ will remain highly uncertain until this imbalance is addressed.

[34] Aside from determining how $\mathrm{R}_{\mathrm{H}}$ is to be measured, if the influence of disturbance on this flux is to be determined experimental design must be considered. One of two methods is typically used to determine the pattern of $R_{H}$ following disturbance. The more common approach is to examine a chronosequence of stand ages [Janisch and Harmon, 2002; Manies et al., 2005; Wirth et al., 2002] to determine changes in fluxes or aboveground $\mathrm{C}$ stores (which has major implication on how $\mathrm{R}_{\mathrm{H}}$ changes). While the immediate effects of disturbance on $\mathrm{R}_{\mathrm{H}}$ can be assessed by means of site comparisons, e.g., between clear-cut and untouched controls [Toland and Zak, 1994] successional chronosequences allow one to assess long-term disturbance effects [Bond-Lamberty et al., 2004a; Howard et al., 2004; O'Neill et al., 2003]. For example, Tang et al. [2009] reported that soil respiration (including $\mathrm{R}_{\mathrm{H}}$ and rhizosphere respiration) after major stand establishing disturbances peaked at intermediate age, and then decreased with age. The advantage of a chronosequence is that it produces a hypothesis of long-term change over a short period of time, but there are major caveats regarding their interpretation [Johnson and Miyanishi, 2008; Pickett, 1989]. The underlying productivity and environment and the disturbances that created the succession must be similar between sites. While the general level of site productivity is possible to control to some extent, climate changes over time and so the longer the chronosequence, the less likely that the climate influencing the development of various aged stand will be similar. Moreover, natural disturbances are highly variable in terms of their frequency and severity which means that sites might have different starting conditions. For example, if one fire leaves a larger legacy than another, then $\mathrm{R}_{\mathrm{H}}$ in a chronosequence could be underestimated or overestimated depending on the sequence of disturbances that occurred. Chronosequence interpretation is also influenced by the number of age-classes examined. Given the potentially nonlinear temporal trend in $R_{H}$ after disturbance examined above, many features may not be discernable if too few age-classes are sampled. Many of the shortcomings of chronosequences can be avoided by sampling over a time series (i.e., measuring over time). While this can take considerable time and resources, there are numerous examples, at least for live carbon pools where this has occurred. There is no reason in theory that either $R_{H}$ or the dead pools contributing to $R_{H}$ could not be followed in a similar manner. The two methods can be combined to examine vectors of change by the resampling of a chronosequence [Bond-Lamberty and Gower, 2008; Harmon et al., 2000; Wirth et al., 2002]. This allows one to observe actual (versus hypothetical) change over a relatively short time period.

\section{Modeling $\mathbf{R}_{\mathbf{H}}$}

[35] Regardless of the number and quality of field estimates of $R_{H}$, it is likely models will be required to make estimates over large areas and long time periods. We believe the current challenge is to be able to predict transient responses (e.g., the impact of changing disturbance regimes) in a temporally and spatially explicit manner. This is because matching inversion and other models requires temporal explicitness in $\mathrm{R}_{\mathrm{H}}$. Moreover, policy decisions regarding carbon balances are likely to be made over large areas, but practical implementation will likely be done at a very local level requiring spatially explicit predictions. Below we review a range of models that have estimated $\mathrm{R}_{\mathrm{H}}$ focusing on the degree to which they can predict temporally and spatially explicit transient responses; a more comprehensive comparison was performed by Wutzler and Reichstein [2008].

[36] The simplest assumption regarding $\mathrm{R}_{\mathrm{H}}$ is that it equals NPP. Since this is based on the assumption the system is in steady state [cf. Harden et al., 1992], it is not possible to use these types of models to predict transient responses. While in theory this kind of model could be used to incorporate disturbance effects, the assumption that NPP equals $R_{H}$ precludes any losses from disturbances such as fires since the substantial loss of combustion from fire does not involve respiration.

[37] Another simplification is to assume that detritus created by disturbance is instantaneously released. While this approach may match average rates over broad areas and puts some constraints on $\mathrm{C}$ pulses associated with disturbance, it would be unlikely to be able to predict transient responses related to changes in disturbance regimes. That is because the "averaging out" this type of model depends upon only occurs when a steady state is present.

[38] It is also possible to aggregate all $\mathrm{R}_{\mathrm{H}}$ components into one flux flowing from a single "soil" pool as in the original version of TEM [McGuire et al., 1992]. As described above, the pools contributing to $R_{H}$ can have turnover times that vary by orders of magnitude. In transient 
conditions such as those following disturbance some pools and their related $R_{H}$ fluxes will therefore respond faster or slower than others. This means that highly aggregated models are unlikely to accurately predict transient responses to disturbance or environmental changes, although they may predict the starting and ending steady states.

[39] A large number of models consider multiple components of $R_{H}$, but differ how they are segregated by turnover time, chemical component, or structural features. The CENTURY model segregates pools along turnover times with microbial (i.e., fast), slow, and passive pools in the soil and in the forest version separate fine and coarse woody detritus pools [Kirschbaum and Paul, 2002; Parton et al., 1993]. Examples of models that segregate by chemical components such as cellulose and lignin include BiomeBGC [Thornton and Rosenbloom, 2005] and GEM [McKane et al., 1997]. The underlying assumption of these models is that lignin decomposes slowly in all substrates, but as discussed above (see section 4) lignin in wood can either decompose slowly or quickly depending on the organisms involved. Therefore, one would need to be able to distinguish the source of the lignin and the type of decomposers present before the rate of loss could be determined. In the case of Biome-BGC, woody detritus is "fragmented" before it can decompose. While woody detritus fragments during decomposition, the way this process is modeled in Biome-BGC cannot be related to empirical studies of wood and bark decomposition, disconnecting this model from any form of direct parameterization.

[40] An alternative model structure, that does not appear to have been generally used, would divide $\mathrm{R}_{\mathrm{H}}$ components into those associated with standing and downed stems, branches, coarse and fine roots, leafy litter, and mineral soil. The advantage of this type of segregation is that it groups components by substrate quality and environment. While all these multicomponent models can be used in a transient mode, most cannot predict the two pulse pattern of $R_{H}$ hypothesized to occur after some disturbances (see section 6), as the moisture environment of all $\mathrm{R}_{\mathrm{H}}$-related pools for most of them is the same. Therefore in certain environments CENTURY, GEM, and Biome-BGC are unlikely to be able to predict the correct temporal pattern of $R_{H}$ at small spatial scales. The potential "mismatch" for the timing of disturbance related $\mathrm{R}_{\mathrm{H}}$ between models that do and do not predict multiple pulses is illustrated in Figure 4 and could be on the order of $10 \%$.

[41] In addition to how the various pools and structures contributing to $\mathrm{R}_{\mathrm{H}}$ are simulated, models vary in the way in which the environment is incorporated. To predict $R_{H}$ accurately it is important that models properly represent environmental controls with appropriate model structure and parameter values [Vargas et al., 2010b]. Some factors, such as temperature, are routinely included while others, such as decomposer functional types (or species), are not. Despite the inclusion of temperature in most models of $R_{H}$, the different ways it is functionally depicted has vastly different consequences in predicting a possible climate-terrestrial carbon positive feedback [Davidson and Janssens, 2006]. Moisture effects, even when directly simulated (versus indirectly approximated via precipitation) generally focus on soil moisture despite the fact that other pools contributing to $\mathrm{R}_{\mathrm{H}}$ (e.g., standing dead trees) are likely to have very dif- ferent moisture balances and regimes. Therefore simulating the correct seasonal pattern of $R_{H}$ would only be possible when the moisture content of all the pools is highly correlated. Even in the case of soil $\mathrm{R}_{\mathrm{H}}$, few models address the effects of short-term drying and wetting cycles, a phenomena that may cause a dampening of long-term $\mathrm{R}_{\mathrm{H}}$ [Laurence et al., 2009].

[42] It is not surprising that forest $\mathrm{C}$ models have a wide variety of approaches to simulating $\mathrm{R}_{\mathrm{H}}$; models are usually designed to work at given spatial and temporal scale and using them outside their designed scale can lead to problems. There is often an assumption that finer-scale processes cancel out at broader scales. While some fine-scale nonlinear behaviors may not exhibit temporal signals at broader temporal spatial scales, this may depend on certain conditions being met. For example, there are many phenomena, such as lags, that are temporally masked when steady state conditions prevail. However, lags do influence the average rates observed at broader scales even under steady state conditions (i.e., the longer the lag time, the more the average rate of a process decreases). When systems change from a steady state to transient condition, then phenomena that only influenced the average rate can start to cause a temporal signal even at the broad scale. Therefore, the cancellation of fine-scale behaviors should be formally confirmed and not simply assumed away. Based on our review, it is unlikely that current models, however good they were for their original purpose and scales, will be able to predict the nonlinear kinds of behavior in $\mathrm{R}_{\mathrm{H}}$ that are being observed in the field or that influence broad-scale changes in $\mathrm{R}_{\mathrm{H}}$ (see Figure 4).

\section{Conclusions and Recommendations for Future Directions}

[43] Estimating, understanding and managing carbon balance in regions in which disturbances are likely to increase in frequency and severity will not be possible unless $R_{H}$ and the factors controlling it are better understood and properly represented in models. As long as disturbances are not considered, one could minimally model $\mathrm{R}_{\mathrm{H}}$ using steady state assumptions using one-pool models, etc. But these models are not realistic when disturbances and transient conditions are present and would make it extremely difficult if not impossible to predict $\mathrm{CO}_{2}$ emissions and future climate conditions, as well as to provide strong support for policy decisions. A new way that acknowledges that disturbances introduce large pulses into system behavior that vary in space and time needs to be developed. Furthermore, the fundamental interactions between disturbance and $R_{H}$ need to be incorporated: unlike live carbon, the slate for dead/soil carbon is rarely wiped clean and this legacy can influence $\mathrm{R}_{\mathrm{H}}$ and hence ecosystem carbon balances (NEP and NECB) for a considerable time period [Foster et al., 1998].

[44] Recommendations to improve our understanding of $\mathrm{R}_{\mathrm{H}}$ include the following:

[45] Better inventory estimates of $\mathrm{C}$ stores in pools contributing to $R_{H}$ are needed. All estimates of fluxes derived from these pools (e.g., fire emissions and $\mathrm{R}_{\mathrm{H}}$ ) currently have a substantial uncertainty. For example, dead wood stores estimates are probably only within $\pm 50 \%$ due to a lack 
adequate of volume to mass conversion factors [Harmon et al., 2008]. While conversion factors are undeniably "mundane," failing to address these issues allows major uncertainties in fluxes to persist. Moreover, since these inventory data are often used to "validate" predictive models, compromised stores estimates ultimately lead to compromised model predictions.

[46] Compared to leaf litter, there is little information on wood decomposition. Some regions of North America have considerable work (e.g., Pacific Northwest) and some have virtually none (e.g., Southwest) compromising broad-scale estimates of $\mathrm{R}_{\mathrm{H}}$. While the recent concern has focused on downed coarse wood other forms such as standing dead, branches, and coarse roots also need to be addressed if the effects of disturbance on $\mathrm{R}_{\mathrm{H}}$ in forests are to be understood. Given the large potential differences in decomposition rates of standing versus downed wood, more information on the rate that standing dead wood falls is essential. Without this information it will be difficult to predict when and where secondary pulses in $\mathrm{R}_{\mathrm{H}}$ will occur.

[47] There is very little work on the physiological controls of $R_{H}$ relative to that on GPP and NPP. There remain substantial questions about the shape of the temperature response, the interaction of substrate quality and temperature sensitivity, the effects of moisture at high levels or during rewetting, and controls related to decomposer organisms (e.g., brown-rot versus white-rot fungi).

[48] The factors controlling moisture balance for aboveground dead biomass need to be better understood. It is readily apparent that soil moisture, in at least time steps shorter than seasonal ones, is not necessarily correlated to the moisture content of the aboveground pools contributing to $\mathrm{R}_{\mathrm{H}}$. If that were the case then the multiple peaks of $\mathrm{R}_{\mathrm{H}}$ release following a disturbance that we hypothesized would not occur.

[49] Disturbances are likely to change physical microclimates in forests and this in turn is likely to change $R_{H}$ in ways that data on macroclimate cannot predict. More attention needs to be placed on determining the magnitude of theses physical changes initiated by disturbances and the subsequent response of decomposers.

[50] An analysis should be undertaken to determine the structure of the $\mathrm{R}_{\mathrm{H}}$ model required to predict the kinds of behaviors that have been observed or are theoretically possible (see section 5). At this point $\mathrm{R}_{\mathrm{H}}$ tends to be treated in a minimalist manner compared to primary production. Models that address the way biotic and physical controls of $\mathrm{R}_{\mathrm{H}}$ vary after disturbance need to be considered. While one should have as simple a model as possible, certain critical behaviors will be impossible to predict if a model is too simple. The traditional assumption that these "finer-scale" behaviors cancel out at broader scales needs to be explicitly tested and not assumed.

[51] A general need that extends beyond $\mathrm{R}_{\mathrm{H}}$ to NEP and NECB is the desirability of having a greater number of replicated postdisturbance chronosequences that are observed over long time periods. Because the $\mathrm{R}_{\mathrm{H}}$ flux pattern over time is influenced by the nature of the disturbance and the nature of the site, a substantial number of chronosequences will be required even within a biome. Moreover, because the $\mathrm{R}_{\mathrm{H}}$ temporal flux can be highly nonlinear, a substantial number of points in time will be required to detect the temporal pattern of this flux.

[52] Acknowledgments. This manuscript was a product of the Disturbance Working Group of the North American Carbon Program. Support was provided by the U.S. Geologic Survey and the Kaye and Ward Richardson Endowment.

\section{References}

Adl, S. (2003), The Ecology of Soil Decomposition, 368 pp., CABI, Wallingford, U. K.

Amiro, B. D. (2001), Paired-tower measurements of carbon and energy fluxes following disturbance in the boreal forest, Global Change Biol., 7, 253-268

Amiro, B. D., A. G. Barr, T. A. Black, and H. Iwashita (2006), Carbon, energy and water fluxes at mature and disturbed forest sites, Saskatchewan, Canada, Agric. For. Meteorol., 136, 237-251.

Austin, A. T., and C. L. Ballare (2010), Dual role of lignin in plant litter decomposition in terrestrial ecosystems, Proc. Natl. Acad. Sci. U. S. A., 107, 4618-4622.

Baldocchi, D. D. (2008), 'Breathing' of the terrestrial biosphere: Lessons learned from a global network of carbon dioxide flux measurement systems, Aust. J. Bot., 56, 1-26.

Baldocchi, D. D., and T. P. Meyers (1991), Trace gas-exchange above the floor of a deciduous forest: 1. Evaporation and $\mathrm{CO}_{2}$ efflux, J. Geophys. Res., 96, 7271-7285.

Boddy, L. (1983), Carbon dioxide release from decomposing wood: Effect of water content and temperature, Soil Biol. Biochem., 15, 501-510.

Bond-Lamberty, B., and S. T. Gower (2008), Decay and fragmentation of coarse woody debris: Revisiting a boreal black spruce chronosequence, Ecosystems, 11, 831-840.

Bond-Lamberty, B., and A. M. Thomson (2010a), A global database of soil respiration data, Biogeosciences, 7, 1915-1926.

Bond-Lamberty, B., and A. M. Thomson (2010b), Temperature-associated increases in the global soil respiration record, Nature, 464, 579-582.

Bond-Lamberty, B., C. Wang, and S. T. Gower (2002), Annual carbon flux from woody debris for a boreal black spruce fire chronosequence, J. Geophys. Res., 107, 8220, doi:10.1029/2001JD000839 [printed 108(D23), 2003].

Bond-Lamberty, B., C. Wang, and S. T. Gower (2004a), Contribution of root respiration to soil surface $\mathrm{CO}_{2}$ flux in a boreal black spruce fire chronosequence, Tree Physiol., 24, 1387-1395.

Bond-Lamberty, B., C. Wang, and S. T. Gower (2004b), Net primary production and net ecosystem production of a boreal black spruce fire chronosequence, Global Change Biol., 10, 473-487.

Boone, R. D., P. Sollins, and K. Cromack Jr. (1998), Roots exert a strong influence on the temperature sensitivity of soil respiration, Nature, 396, $570-572$.

Bormann, B. T., P. S. Homann, R. L. Darbyshire, and B. A. Morrissette (2008), Intense forest wildfire sharply reduces mineral soil $\mathrm{C}$ and $\mathrm{N}$ : The first direct evidence, Can. J. For. Res., 38, 2771-2783.

Boulanger, Y., and L. Sirois (2006), Postfire dynamics of black spruce coarse woody debris in northern boreal forest of Quebec, Can. J. For. Res., 36, 1770-1780.

Brackebusch, A. P. (1975), Gain and loss of moisture in large forest fuels, Res. Pap. INT-173, 50 pp., For. Serv., U.S. Dep. of Agric., Ogden, Utah. Bradford, M. A., C. A. Davies, S. D. Frey, T. R. Maddox, J. M. Melillo, J. E. Mohan, J. F. Reynolds, K. K. Treseder, and M. D. Wallenstein (2008), Thermal adaptation of soil microbial respiration to elevated temperature, Ecol. Lett., 11, 1316-1327.

Bradford, M. A., B. W. Watts, and C. A. Davies (2010), Thermal adaptation of heterotrophic soil respiration in laboratory microcosms, Global Change Biol., 16, 1576-1588.

Brandt, L. A., C. Bohnet, and J. Y. King (2009), Photochemically induced carbon dioxide production as a mechanism for carbon loss from plant litter in arid ecosystems, J. Geophys. Res., 114, G02004, doi:10.1029/ 2008JG000772.

Bunnell, F. L., D. E. N. Tait, P. W. Flanagan, and K. Van Cleve (1977), Microbial respiration and substrate loss. I. A general model of the influences of abiotic factors, Soil Biol. Biochem., 9, 33-40.

Byram, G. M., and G. M. Jemison (1943), Solar radiation and forest fuel moisture, J. Agric. Res., 67, 149-176.

Chambers, J. Q., J. P. Schimel, and A. D. Nobre (2001), Respiration from coarse wood litter in central Amazon forests, Biogeochemistry, 52, $115-131$. 
Chapin, F. S., et al. (2006), Reconciling carbon-cycle concepts, terminology, and methods, Ecosystems, 9, 1041-1050.

Christenssen, O. (1977), Estimation of standing crop and turnover of dead wood in a Danish oak forest, Oikos, 28, 177-186.

Clark, D. A., S. Brown, D. W. Kicklighter, J. Q. Chambers, J. R. Thomlinson, and J. Ni (2001), Measuring net primary production in forests: Concepts and field methods, Ecol. Appl., 11, 356-370.

Conant, R. T., J. M. Steinweg, M. L. Haddix, E. A. Paul, A. F. Plante, and J. Six (2008), Sensitivity of organic matter decomposition to warming varies with its quality, Global Change Biol., 14, 868-877.

Cooper-Ellis, S., D. R. Foster, G. Carlton, and A. Lezberg (1999), Forest response to catastrophic wind: Results from an experimental hurricane, Ecology, 80, 2683-2696.

Coûteaux, M. M., P. Bottner, and B. Berg (1995), Litter decomposition, climate and litter quality, Trends Ecol. Evol., 10, 63-66.

Curiel Yuste, J., D. D. Baldocchi, A. Gershenson, A. Goldstein, L. Mission, and S. Wong (2007), Microbial soil respiration and its dependency on carbon inputs, soil temperature and moisture, Global Change Biol., $13,1-18$.

Davidson, E. A., and I. A. Janssens (2006), Temperature sensitivity of soil carbon decomposition and feedbacks to climate change, Nature, 440, $165-173$.

Davidson, E. A., et al. (2002), Belowground carbon allocation in forests estimated from litterfall and IRGA-based soil respiration measurements, Agric. For. Meteorol., 113, 39-51.

Davidson, E. A., A. D. Richardson, K. E. Savage, and D. Y. Hollinger (2006), A distinct seasonal pattern of the ratio of soil respiration to total ecosystem respiration in a spruce-dominated forest, Global Change Biol., $12,230-239$.

Deng, F., J. M. Chen, M. Ishizawa, C.-W. Yuen, G. Mo, K. Higuchi, D. Chan, and S. Maksyutov (2007), Global monthly $\mathrm{CO}_{2}$ flux inversion with a focus over North America, Tellus, Ser. B, 59, 179-190.

Diochon, A. C., and L. Kellman (2009), Physical fractionation of soil organic matter: Destabilization of deep soil carbon following harvesting of a temperate coniferous forest, J. Geophys. Res., 114, G01016, doi:10.1029/2008JG000844.

Enloe, H. A., R. C. Graham, and S. C. Sillett (2006), Arboreal histosols in old-growth redwood forest canopies, northern California, Soil Sci. Soc. Am. J., 70, 408-418.

Epron, D., L. Farque, E. Lucot, and P.-M. Badot (1999), Soil $\mathrm{CO}_{2}$ efflux in a beech forest: The contribution of root respiration, Ann. For. Sci., 56 , 289-295.

Fang, C., P. Smith, J. B. Moncrieff, and J. U. Smith (2005), Similar response of labile and resistant soil organic matter pools to changes in temperature, Nature, 433, 57-59.

Fierer, N., and J. Schimel (2002), Effects of drying-rewetting frequency on soil carbon and nitrogen transformations, Soil Biol. Biochem., 34 $777-787$.

Fierer, N., J. M. Craine, K. McLaughlan, and J. P. Schimel (2005), Litter quality and the temperature sensitivity of decomposition, Ecology, 86, 320-326.

Fisher, J. I., G. C. Hurtt, R. Q. Thomas, and J. Q. Chambers (2008), Clustered disturbances lead to bias in large-scale estimates based on fores sample plots, Ecol. Lett., 11, 554-563.

Fissore, C., C. P. Giardina, C. W. Swanston, G. M. King, and R. K. Kolka (2009), Variable temperature sensitivity of soil organic carbon in North American forests, Global Change Biol., 15, 2295-2310.

Fosberg, M. A. (1971), Climatological influences on moisture characteristics of dead fuel: Theoretical analysis, For. Sci., 17, 64-72.

Foster, D. R., D. H. Knight, and J. F. Franklin (1998), Landscape patterns and legacies resulting from large, infrequent forest disturbances, Ecosystems, 1, 497-510.

Fritze, H., T. Pennanen, and J. Pietikainen (1993), Recovery of soil microbial biomass and activity from prescribed burning, Can. J. For. Res., 23, 1286-1290.

Gershenson, A., N. E. Bader, and W. X. Cheng (2009), Effects of substrate availability on the temperature sensitivity of soil organic matter decomposition, Global Change Biol., 15, 176-183.

Giardina, C. P., and M. G. Ryan (2000), Evidence that decomposition rates of organic carbon in mineral soil do not vary with temperature, Nature, $404,858-861$

Gilbertson, R. L. (1980), Wood-rotting fungi of North America, Mycologia, $72,1-49$

Gough, C. M., C. S. Vogel, C. Kazanski, L. Nagel, C. E. Flower, and P. S. Curtis (2007), Coarse woody debris and the carbon balance of a north temperate forest, For. Ecol. Manage., 244, 60-67.

Goulden, M. L., and P. M. Crill (1997), Automated measurements of CO exchange at the moss surface of a black spruce forest, Tree Physiol., 17 , $537-542$.
Goulden, M. L., A. M. S. McMillan, G. C. Winston, A. V. Rocha, K. L. Manies, J. W. Harden, and B. P. Bond-Lamberty (2010), Patterns of NPP, GPP, respiration and NEP during boreal forest succession, Global Change Biol., 17, 855-871.

Graf, A., L. Weirmüller, J. A. Huisman, M. Herbst, J. Bauer, and H. Vereeken (2008), Measurement depth effects on the apparent temperature sensitivity of soil respiration in field studies, Biogeosciences, 5, 1175-1188.

Griffin, D. M. (1977), Water potential and wood-decay fungi, Annu. Rev. Phytopathol., 15, 319-329.

Hahn, V., P. Hőberg, and N. Buchmann $(2006),{ }^{14} \mathrm{C}-$ a tool for separation of autotrophic and heterotrophic soil respiration, Global Change Biol., 12, 972-982.

Hakkenberg, R., G. Churkina, M. Rodeghiero, A. Borner, A. Steinhof, and A. Cescatti (2008), Temperature sensitivity of the turnover times of soil organic matter in forests, Ecol. Appl., 18, 119-131.

Hanson, P. J., N. T. Edwards, C. T. Garten, and J. A. Andrews (2000), Separating root and soil microbial contributions to soil respiration: A review of methods and observations, Biogeochemistry, 48, 115-146.

Harden, J. W., R. K. Mark, E. T. Sundquist, and R. F. Stallard (1992) Dynamics of soil carbon during deglaciation of the Laurentide ice sheet, Science, 258, 1921-1924.

Harmon, M. E. (1992), Long term experiments on log decomposition at the H. J. Andrews Experimental Forest, Gen. Tech. Rep. PNW GTR 280 28 pp., For. Serv., U.S. Dep. of Agric., Portland, Oreg.

Harmon, M. E. (2009), Woody detritus mass and its contribution to carbon dynamics of old-growth forests: The temporal context, in Old-Growth Forests: Function, Fate and Value, Ecol. Stud., vol. 207, edited by C. Wirth, G. Gleixner, and M. Heimann, pp. 159-189, Springer, New York.

Harmon, M. E., et al. (1986), Ecology of coarse woody debris in temperate ecosystems, Adv. Ecol. Res, 15, 133-302.

Harmon, M. E., D. F. Whigham, J. Sexton, and I. Olmsted (1995), Decomposition and stores of woody detritus in the dry tropical forests of the northeastern Yucatan Peninsula, Mexico, Biotropica, 27, 305-316.

Harmon, M. E., S. L. Garman, and W. K. Ferrell (1996), Modeling historical patterns of tree utilization in the Pacific Northwest: Carbon sequestration implications, Ecol. Appl., 6, 641-652.

Harmon, M. E., O. N. Krankina, and J. Sexton (2000), Decomposition vectors: A new approach to estimating woody detritus decomposition dynamics, Can. J. For. Res., 30, 76-84

Harmon, M. E., K. Bible, M. J. Ryan, D. Shaw, H. Chen, J. Klopatek, and X. Li (2004), Production, respiration, and overall carbon balance in an old-growth Pseudotsuga-tsuga forest ecosystem, Ecosystems, 7, 498-512.

Harmon, M. E., C. W. Woodall, B. Fasth, and J. Sexton (2008), Woody detritus density and density reduction factors for tree species in the United States: A synthesis, Gen. Tech. Rep. NRS-29, 84 pp., North. Res. Stn., For. Serv., U.S. Dep. of Agric., Newtown Square, Pa.

Hillel, D. (1998), Environmental Soil Physics: Fundamentals, Applications, and Environmental Consideratons, 771 pp., Academic, San Diego, Calif. Högberg, P., A. Nordgren, N. Buchmann, A. F. S. Taylor, A. Ekbald, M. N Högberg, G. Nyberg, M. Ottosson-Löfvenius, and D. J. Read (2001), Large-scale forest girdling shows that current photosynthesis drives soil respiration, Nature, 411, 789-792.

Houghton, R. A. (2003), Revised estimates of the annual net flux of carbon to the atmosphere from changes in land use and land management 1850-2000, Tellus, Ser. B, 55, 378-390.

Houghton, R. A., F. G. Hall, and S. J. Goetz (2009), Importance of biomass in the global carbon cycle, J. Geophys. Res., 114, G00E03, doi:10.1029/ 2009JG000935.

Howard, D., and P. Howard (1993), Relationships between $\mathrm{CO}_{2}$ evolution, moisture content, and temperature for a range of soil types, Soil Biol. Biochem. 25, 1537-1546.

Howard, E. A., S. T. Gower, J. A. Foley, and C. J. Kucharik (2004), Effects of logging on carbon dynamics of a jack pine forest in Saskatchewan, Canada, Global Change Biol., 10, 1267-1284.

Janisch, J. E., and M. E. Harmon (2002), Successional changes in live and dead wood carbon stores: Implications for net ecosystem productivity, Tree Physiol., 22, 77-89.

Jassal, R. S., and T. A. Black (2006), Estimating heterotrophic and autotrophic soil respiration using small-area trenched plot technique: Theory and practice, Agric. For. Meteorol., 140, 193-202.

Jassal, R. S., A. Black, M. Novak, K. Morgenstern, Z. Nesic, and D. Gaumont-Guay (2005), Relationship between soil $\mathrm{CO}_{2}$ concentrations and forest-floor $\mathrm{CO}_{2}$ effluxes, Agric. For. Meteorol., 130, 176-192.

Johnson, E. A., and K. Miyanishi (2008), Testing the assumptions of chronosequences in succession, Ecol. Lett., 11, 419-431.

Jomura, M., Y. Kominami, K. Tamai, T. Miyama, Y. Goto, M. Dannoura, and Y. Kanazawa (2007), The carbon budget of coarse woody debris in a 
temperate broad-leaved secondary forest in Japan, Tellus, Ser. B, 59(2), 211-222.

Keeley, J. E. (2009), Fire intensity, fire severity and burn severity: A brief review and suggested usage, Int. J. Wildland Fire, 18, 116-126.

Kirk, T. K., and T. L. Highley (1973), Quantitative changes in structural components of conifer woods during decay by white- and brown-rot fungi, Phytopathology, 63, 1337-1342.

Kirschbaum, M. U. F. (2006), The temperature dependence of organicmatter decomposition-Still a topic of debate, Soil Biol. Biochem., 38, 2510-2518.

Kirschbaum, M. U. F., and K. I. Paul (2002), Modelling C and N dynamics in forest soils with a modified version of the CENTURY model, Soil Biol. Biochem., 34, 341-354.

Kurz, W. A., C. C. Dymond, G. Stinson, G. J. Rampley, E. T. Neilson A. L. Carroll, T. Ebata, and L. Safranyik (2008), Mountain pine beetle and forest carbon feedback to climate change, Nature, 452, 987-990.

Kuzyakov, Y., and A. A. Larionova (2005), Root and rhizomicrobial respiration: A review of approaches to estimate respiration by autotrophic and heterotrophic organisms in soil, J. Plant Nutr. Soil Sci., 168, 503-520.

Lambert, R. L., G. E. Lang, and W. A. Reiners (1980), Loss of mass and chemical change in decaying boles of a subalpine balsam fir forest, Ecology, 61, 1460-1473

Laurence, C. R., J. F. Neff, and J. P. Schimel (2009), Does adding microbial mechanisms of decomposition improve soil organic matter models? A comparison of four models using data from a pulsed rewetting experiment, Soil Biol. Biochem., 41, 1923-1934.

Lavigne, M. B., et al. (1997), Comparing nocturnal eddy covariance measurements to estimates of ecosystem respiration made by scaling chamber measurements at six coniferous boreal sites, J. Geophys. Res., 102 , $28,977-28,985$

Law, B. E., D. D. Baldocchi, and P. M. Anthoni (1999), Seasonal and annual respiration of a ponderosa pine ecosystem, Global Change Biol., $5,169-182$

Litvak, M., S. Miller, S. C. Wofsy, and M. Goulden (2003), Effect of stand age on whole ecosystem $\mathrm{CO}_{2}$ exchange in the Canadian boreal forest, J. Geophys. Res., 108(D3), 8225, doi:10.1029/2001JD000854.

Livingston, G. P., and G. L. Hutchinson (1995), Biogenic Trace Gases: Measuring Emissions From Soil and Water, edited by P. A. Matson and R. C. Harriss, pp. 14-51, Blackwell Sci., London.

Lloyd, J., and J. A. Taylor (1994), On the temperature dependence of soil respiration, Funct. Ecol., 8, 315-323.

Luo, Y., S. Q. Wan, D. F. Hui, and L. L. Wallace (2001), Acclimatization of soil respiration to warming in a tall grass prairie, Nature, 413, 622-625.

Luyssaert, S., E.-D. Schulze, A. Borner, A. Knohl, D. Hessenmoller, B. E. Law, P. Ciais, and J. Grace (2008), Old-growth forests as global carbon sinks, Nature, 455, 213-215.

Mackensen, J., J. Bauhus, and E. Webber (2003), Decomposition rates of coarse woody debris- A review with particular emphasis on Australian tree species, Aust. J. Bot., 51, 27-37.

Mahecha, M. D., et al. (2010), Global convergence in the temperature sensitivity of respiration at ecosystem level, Science, 329, 838-840.

Manies, K. L., J. W. Harden, B. P. Bond-Lamberty, and K. P. O'Neil (2005), Woody debris along an upland chronosequence in boreal Manitoba and its impact on long-term carbon storage, Can. J. For. Res., 35, $472-482$.

Marra, J. L., and R. L. Edmonds (1996), Coarse woody debris and soil respiration in a clearcut on the Olympic Peninsula, Washington, U.S, Can J. For. Res., 26, 1337-1345.

McGuire, A. D., J. M. Melillo, L. A. Joyce, D. W. Kicklighter, A. L. Grace, B. Moore III, and C. J. Vorosmarty (1992), Interactions between carbon and nitrogen dynamics in estimating net primary productivity for potential vegetation in North America, Global Biogeochem. Cycles, 6, 101-124.

McKane, R. B., E. B. Rastetter, G. R. Shaver, K. J. Nadelhoffer, A. E Giblin, J. A. Laundre, and F. S. Chapin III (1997), Climatic effects on tundra carbon storage inferred from experimental data and a model, Ecology, 78, 1170-1187.

Melillo, J. M., J. D. Aber, and J. F. Murtore (1982), Nitrogen and lignin control of hardwood leaf litter decomposition dynamics, Ecology, 63, 621-626.

Mo, W., M.-S. Lee, M. Uchida, M. Inatomi, N. Saigusa, M. Shigeru, and H. Koizumi (2005), Seasonal and annual variations in soil respiration in a cool-temperate deciduous broad-leaved forest in Japan, Agric. For. Meteorol., 134, 81-94.

Moroni, M. T. (2006), Disturbance history affects dead wood abundance in Newfoundland boreal forests, Can. J. For. Res., 36, 3194-3208.

Odum, E. P. (1969), The strategy of ecosystem development, Science, 164, $262-270$.
'Neill, K. P., E. S. Kasischke, and D. D. Richter (2003), Seasonal and decadal patterns of soil carbon uptake and emission along an age sequence of burned black spruce stands in interior Alaska, J. Geophys. Res., 108(D1), 8155, doi:10.1029/2001JD000443.

Orchard, V. A., and F. J. Cook (1983), Relationship between soil respiration and soil moisture, Soil Biol. Biochem., 15, 447-453.

Ostertag, R., F. N. Scatena, and W. L. Silver (2003), Forest floor decomposition following hurricane litter inputs in several Puerto Rican forests, Ecosystems, 6, 261-273.

Pan, Y., J. M. Chen, R. Birdsey, K. McCullough, L. He, and F. Deng (2010), Age structure and disturbance legacy of North American forests, Biogeosciences Discuss., 7, 979-1020.

Parton, W. J., et al. (1993), Observations and modeling of biomass and soil organic matter dynamics for the grassland biome worldwide, Global Biogeochem. Cycles, 7, 785-809.

Pedlar, J. H., J. L. Pearce, L. A. Venier, and D. W. McKenney (2002), Coarse woody debris in relation to disturbance and forest type in boreal Canada, For. Ecol. Manage., 158, 189-194.

Pickett, S. T. A. (1989), Space-for-time substitution as an alternative to long-term studies, in Long-Term Studies in Ecology: Approaches and Alternatives, edited by G. E. Likens, pp. 110-135, Springer, New York.

Pickett, S. T. A., and P. S. White (1985), The Ecology of Natural Disturbance and Patch Dynamics, 450 pp., Academic, Orlando, Fla.

Pietikäinen, J., and H. Fritze (1993), Microbial biomass and activity in the humus layer following burning: Short-term effects of two different fires, Can. J. For. Res., 23, 1275-1285.

Potter, C. S., and S. Klooster (1998), Interannual variability in soil trace gas $\left(\mathrm{CO}_{2}, \mathrm{~N}_{2} \mathrm{O}, \mathrm{NO}\right)$ fluxes and analysis of controllers on regional to global scales, Global Biogeochem. Cycles, 12, 621-635.

Preston, C. M., J. A. Trofymow, B. G. Sayer, and J. Niu (1997), Super ${ }^{13}$ C nuclear magnetic resonance spectroscopy with cross-polarization and magic-angle spinning investigation of the proximate-analysis fractions used to assess litter quality in decomposition studies, Can. J. Bot., 75, 1601-1613.

Roberts, M. R. (2004), Response of the herbaceous layer to natural disturbance in North America forests, Can. J. Bot., 82, 1273-1283.

Roberts, M. R. (2007), A conceptual model to characterize disturbance severity in forest harvests, For. Ecol. Manage., 242, 58-64.

Rock, J., F.-W. Badek, and M. E. Harmon (2008), Estimating decomposition rate constants for European tree species from literature sources, Eur. J. For. Res., 127, 301-313.

Rothermel, R., R. A. Wilson Jr., G. A. Morris, and S. S. Sackett (1986), Modeling moisture content of fine dead wildland fuels: Input to the BEHAVE fire prediction system, Res. Pap. INT-359, 61 pp., For. Serv. U.S. Dep. of Agric., Ogden, Utah.

Rustad, L. E., T. G. Huntington, and R. D. Boone (2000), Controls on soil respiration: Implications for climate change, Biogeochemistry, 48, 1-6.

Ryan, M. G., J. M. Melillo, and A. Ricca (1990), A comparison of methods for determining proximate carbon fractions of forest litter, Can. J. For. Res., 20, 166-171.

Sampson, D. A., I. A. Janssens, J. Curiel Yuste, and R. Ceulemans (2007), Basal rates of soil respiration are correlated with photosynthesis in a mixed temperate forest, Global Change Biol., 13, 2008-2017.

Scheffer, T. C., and E. B. Cowling (1966), Natural resistance of wood to microbial deterioration, Annu. Rev. Phytopathol., 4, 147-170.

Scott-Denton, L. E., T. N. Rosenstiel, and R. K. Monson (2006), Differential controls by climate and subtrate over the heterotrophic and rhizospheric components of soil respiration, Global Change Biol., 12, 205-216.

Silver, W. L., and R. K. Miya (2001), Global patterns in root decomposition: Comparisons of climate and litter quality effects, Oecologia, 129, 407-419.

Simard, A. J., and W. A. Main (1982), Comparing methods of predicting Jack pine slash moisture, Can. J. For. Res., 12, 793-802.

Six, J., P. Callewaert, S. Lenders, S. De Gryze, S. J. Morris, E. G. Gregorich, E. A. Paul, and K. Paustian (2002), Measuring and understanding carbon storage in afforested soils by physical fractionation, Soil Sci. Soc. Am. J., 66, 1981-1987.

Smith, W. K., W. Gao, H. Steltzer, M. D. Wallenstein, and R. Tree (2010), Moisture availability influences the effect of ultraviolet-B radiation on leaf litter decomposition, Global Change Biol., 16, 484-495.

Smithwick, E. A. H., M. E. Harmon, and J. B. Domingo (2007), Changing temporal patterns of forest carbon stores and net ecosystem carbon balance: The stand to landscape transformation, Landscape Ecol., 22, 77-94.

Sollins, P., P. Homann, and B. A. Caldwell (1996), Stabilization and destabilization of soil organic matter: Mechanisms and controls, Geoderma $74,65-105$

Storaunet, K. O., and J. Rolstad (2004), How long do Norway spruce snags stand? Evaluating four sestimation methods, Can. J. For. Res., $34,376-383$ 
Tang, J., and D. D. Baldocchi (2005), Spatial-temporal variation in soil respiration in an oak-grass savanna ecosystem in California and its partitioning into autotrophic and heterotrophic components, Biogeochemistry, 73, 183-207.

Tang, J., D. D. Baldocchi, Y. Qi, and L. Xu (2003), Assessing soil $\mathrm{CO}_{2}$ efflux using continuous measurements of $\mathrm{CO}_{2}$ profiles in soils with small solid-state sensors, Agric. For. Meteorol., 118, 207-220.

Tang, J., L. Misson, A. Gershenson, W. X. Cheng, and A. H. Goldstein (2005), Continuous measurements of soil respiration with and without roots in a ponderosa pine plantation in the Sierra Nevada Mountains, Agric. For. Meteorol., 132, 212-227.

Tang, J., P. V. Bolstad, A. R. Desai, J. G. Martin, B. D. Cook, K. J. Davis, and E. V. Carey (2008), Ecosystem respiration and its components in an old-growth northern forest, Agric. For. Meteorol., 148, 171-185.

Tang, J., P. V. Bolstad, and J. G. Martin (2009), Soil carbon fluxes and stocks in a Great Lakes forest chronosequence, Global Change Biol., $15,145-155$.

Thornton, P. E., and N. A. Rosenbloom (2005), Ecosystem model spin-up: Estimating steady state conditions in a coupled terrestrial carbon and nitrogen cycle model, Ecol. Modell., 189, 25-48.

Toland, D. E., and D. R. Zak (1994), Seasonal patterns in soil respiration in intact and clear-cut northern hardwood forests, Can. J. For. Res., 24, 1711-1716.

Trumbore, S. E. (2006), Carbon respired by terrestrial ecosystems-recent progress and challenges, Global Change Biol., 12, 141-153.

Unestan, T. (1991), Water repellency, mat formation, and leaf stimulated growth of some ecomycorrhizal fungi, Mycorrhiza, 1, 13-20.

U.S. Climate Change Science Program (2007), The first State of the Carbon Cycle Report (SOCCR): The North American carbon budget and implications for the global carbon cycle, edited by A. W. King et al., Natl. Clim. Data Cent., Natl. Oceanic and Atmos. Admin., Asheville, N. C.

Vargas, R., and M. F. Allen (2008), Diel patterns of soil respiration in a tropical forest after Hurricane Wilma, J. Geophys. Res., 113, G03021, doi:10.1029/2007JG000620.

Vargas, R., et al. (2010a), Looking deeper into the soil: Environmental controls and seasonal lags of soil $\mathrm{CO}_{2}$ production and efflux across multiple vegetation types, Ecol. Appl., 20, 1569-1582.

Vargas, R., M. S. Carbone, M. Riechstein, and D. D. Baldocci (2010b), Frontiers and challenges in soil respiration research: From measurements to model-data integration, Biogeochemistry, 102, 1-13.

Vargas, R., M. Detto, D. D. Baldocchi, and M. F. Allen (2010c), Multiscale analysis of temporal variability of soil $\mathrm{CO}_{2}$ production as influenced by weather and vegetation, Global Change Biol., 16, 1589-1605.
Viney, N. R. (1991), A review of fine fuel moisture modeling, Int. J. Wildland Fire, 1, 215-234.

Vogt, K. A., C. C. Grier, C. E. Meier, and R. L. Edmonds (1982), Mycorrhizal role in net primary production and nutrient cycling in Abies amabilis ecosystems in western Washington, Ecology, 63, 370-380.

Wang, C., B. Bond-Lamberty, and S. T. Gower (2002), Environmental controls on $\mathrm{CO}_{2}$ flux from black spruce coarse woody debris, Oecologia 132, 374-381.

Wirth, C., E.-D. Schultze, B. Luhkey, S. Grigoriev, M. Siry, G. Hardes, W. Ziegler, M. Backer, G. Bauer, and N. N. Vygodskaya (2002), Fire and site type effects on the long-term carbon and nitrogen balance in pristine Siberian Scots pine forests, Plant Soil, 242, 41-63.

Wood, T. G. (1976), The role of termites (Isoptera) in decomposition processes, in The Role of Terrestrial and Aquatic Organisms in Decomposition Processes (Symposium of the British Ecological Society), edited by J. M. Anderson and A. Macfadyen, pp. 145-168, Blackwell Sci., London.

Wutzler, T, and M. Reichstein (2008), Colimitation of decomposition by substrate and decomposers - A comparison of model formulations, Biogeosciences, 5, 749-759.

Zeng, H., J. Q. Chamber, R. I. Negrón-Juárez, G. C. Hurtt, D. B. Baker, and M. D. Powell (2009), Impacts of tropical cyclones in U.S. forest tree mortality and carbon flux from 1851 to 2000, Proc. Natl. Acad. Sci. U. S. A., 106, 7888-7892.

Zhou, T., S. Peigun, D. Hui, and Y. Lao (2009), Global pattern of temperature sensitivity of soil heterotrophic respiration $(\mathrm{Q}(10))$ and its implications for carbon-climate feedback, J. Geophys. Res., 114, G02016, doi:10.1029/2008JG000850.

B. Bond-Lamberty, Joint Global Change Research Institute, Pacific Northwest National Laboratory/University of Maryland, College Park, MD 20740, USA. (bondlamberty@pnl.gov)

M. E. Harmon, Department of Forest Ecosystems and Society, Oregon State University, Corvallis, OR 97331, USA. (mark.harmon@ oregonstate.edu)

J. Tang, The Ecosystems Center, Marine Biological Laboratory, Woods Hole, MA 02543, USA. (jtang@mbl.edu)

R. Vargas, Departamento de Biología de la Conservación, Centro de Investigación Científica y de Educación Superior de Ensenada, Ensenada, BC 22860, Mexico. (rvargas@cicese.mx) 